\title{
An international scoping review of rangers' precarious employment conditions
}

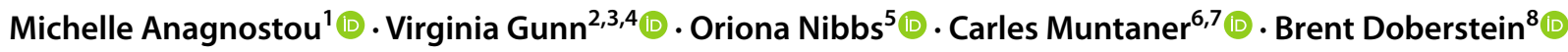

Accepted: 18 January 2022 / Published online: 1 February 2022

(c) The Author(s), under exclusive licence to Springer Science+Business Media, LLC, part of Springer Nature 2022

\begin{abstract}
Protecting wildlife and other natural resources requires engaging and empowering local communities, ensuring compliance with rules, and ongoing monitoring and research. At the frontline of these efforts are rangers. Despite their critical role in maintaining the integrity of parks and protected areas, rangers across the world are exposed to precarious employment conditions and hazardous work environments. We conducted an international scoping review to understand which employment and working conditions are examined in the context of the ranger occupation and to assess whether the concept of precarious employment is used in the conservation, criminological, and environmental sustainability literature on rangers. We reviewed publications from Web of Knowledge, Scopus, ProQuest, and Medline, and grey literature for relevant English language articles published between 2000 and 2021. Our findings are based on the analysis of 98 included studies. We found that the most commonly discussed aspect of rangers' employment and working conditions was the hazardous social and physical work environment, although this was often accompanied by severe income inadequacy, employment insecurity, and a lack of social security, regulatory support, and workplace rights. Such employment and working conditions can cause adverse impacts on rangers' mental and physical health, well-being, and safety, and are also detrimental to their ability to adequately protect biodiversity. We conclude by outlining the need for sustainable solutions and additional research based on established conceptualizations of the precarious employment concept and other related concepts. Lastly, we suggest that governments should acknowledge the importance of rangers through their recognition as essential workers and provide greater support to improve their employment conditions.
\end{abstract}

Keywords Decent work · Occupational health $\cdot$ Conservation officer $\cdot$ Job quality $\cdot$ Protected areas $\cdot$ Sustainable development

Michelle Anagnostou

managnos@uwaterloo.ca; michanagnostou@hotmail.ca

Virginia Gunn

virginia.gunn@utoronto.ca

Oriona Nibbs

onibbs@uwaterloo.ca

Carles Muntaner

carles.muntaner@utoronto.ca

Brent Doberstein

bdoberst@uwaterloo.ca

1 Geography and Environmental Management, University of Waterloo, Waterloo, ON, Canada

2 MAP Centre for Urban Health Solutions, Li Ka Shing Knowledge Institute, Unity Health Toronto, Toronto, ON, Canada
3 Unit of Occupational Medicine, The Institute of Environmental Medicine, Karolinska Institute, Stockholm Region, Sweden

4 Lawrence S. Bloomberg Faculty of Nursing, University of Toronto, Toronto, ON, Canada

5 Environment, Resources and Sustainability, University of Waterloo, Waterloo, ON, Canada

6 Lawrence S. Bloomberg Faculty of Nursing, University of Toronto, Toronto, ON, Canada

7 Dalla Lana School of Public Health, University of Toronto, Toronto, ON, Canada

8 Geography \& Environmental Management, University of Waterloo, Waterloo, ON, Canada 


\section{Introduction}

Rangers are at the frontline of efforts to conserve biodiversity around the world (Singh et al. 2021a). The estimated 1.5 million rangers who are currently active (McPherson 2021) can have a variety of diverse roles and responsibilities, yet all of them work towards ensuring that wildlife and other natural resources are being protected. For instance, rangers may be involved in (i) engaging local communities in biodiversity conservation, (ii) wildlife and general law enforcement, (iii) supporting tourism activities and recreation, (iv) biological monitoring, (v) relocating wildlife, (vi) collecting, managing and analysing data, (vii) mitigating human-wildlife conflict (HWC), (viii) providing education and awareness, and/or (ix) guarding national borders (Kuiper et al. 2021; Ogunjinmi et al. 2008; Pashkevich and Stjernström 2014; Singh et al. 2021a). The International Ranger Federation defines a ranger as someone who is "responsible for safeguarding nature, and cultural and historical heritage, and protecting the rights and well-being of present and future generations" and who "provides recreational opportunities and interpretation of sites while providing links between local communities, protected areas and area administration" (International Ranger Federation 2020, 2021). Given the nature of their work, rangers often work in challenging and dangerous conditions, including the threat of encountering armed intruders, dangerous wildlife, extreme weather conditions, and contracting infectious diseases (Belecky et al. 2021).

Previous studies have investigated the impact of individual ranger characteristics, role complexity, role progression, and hazardous work environments on rangers' safety (Baker et al. 2012; Eliason 2011; Pennaz 2017), health (International Labour Organization 2020; Krake et al. 2003), occupational stress (Ledford et al. 2021; Moreto et al. 2015), well-being (Singh et al. 2021b), and job satisfaction (Spira et al. 2019). A growing body of literature has examined or discussed the impact of factors such as employment relations (Moreto et al. 2015; Poppe 2012; Singh et al. 2020), income level (Kuiper et al. 2021; Poppe 2012; Thakholi 2021), workplace rights and protections (Moreto et al. 2015; Thakholi 2021; World Wildlife Fund 2018b, 2019) and other employment aspects, including schedule predictability and working hours (Moreto et al. 2015; Spira et al. 2019; World Wildlife Fund 2019), on rangers' health and other well-being indicators, thus addressing the well-established links between employment conditions and workers' health (Jonsson et al. 2021; Julià et al. 2017; Lewchuk 2017; Matilla-Santander et al. 2019; Muntaner et al. 2010, 2020; Rönnblad et al. 2019).

Given the wide range and complexity of employment arrangements and contextual factors that could affect rangers' health and well-being, the accurate study of related exposures and outcomes requires a systematic and consistent approach that uses established theoretical frameworks and operationalizations (Benach and Muntaner 2007; Benach et al. 2010; Bodin et al. 2019; Kreshpaj et al. 2020; Vives et al. 2010). For instance, in an effort to address previous research limitations related to the exclusion of employment conditions from occupational health research on working conditions (Benach and Muntaner 2007; Muntaner and O'Campo 1993) along with study design deficiencies and biased assessments of employment-related exposures, the concept of precarious employment is increasingly used to define and categorize employment-related factors and study their impact on workers' health and well-being (Benach and Muntaner 2007; Benach et al. 2016, 2014; Bodin et al. 2019; Jonsson et al. 2021). Currently, there is no accepted definition but, instead, many explanations and approaches are used to define precarious employment, which can lead to several methodological challenges (Bodin et al. 2019; International Labour Organization 2016; Kreshpaj et al. 2020), especially when trying to compare and combine findings across regions, economic sectors, and population subgroups. Within the fields of public health and social and occupational epidemiology, precarious employment has been described as a multifaceted construct that includes employment insecurity, income insufficiency, and lack of rights and protection in the employment relation, including no protection against problematic working conditions (Benach and Muntaner 2007; Hadden et al. 2007; International Labour Organization 2016; Kreshpaj et al. 2020).

Employment precarity could be located on a continuum, with standard employment, characterized by full-time, nonseasonal, and unlimited-duration contracts at one end and a high degree of employment instability-including contractual relationship insecurity and temporariness, income insufficiency, and lack of rights, benefits, and protection in the employment relationship_-at the other end (Hadden et al. 2007; Kreshpaj et al. 2020). Although, as a determinant of population health and health disparities, precarious employment conditions could affect workers in all economic sectors and in all countries around the world (Benach et al. 2014), its prevalence is higher among certain occupations and populations. As substantiated in a range of studies discussing the impacts of precarity on diverse population sub-groups, precarious employment is unevenly distributed, being more prevalent among groups that experience other types of socially created inequities related to, for example, race, age, gender, income, class, education, immigration status, and disability (Bodin et al. 2019; Gunn et al. 2021a; Lewchuk 2017; Muntaner et al. 2020).

The number of studies examining both the (i) relationships between precarious employment conditions and health 
outcomes (including occupational and musculoskeletal injuries, deficient self-rated health, reduced well-being, destructive health behaviours, various cancers, and mental health, cardiovascular, kidney, liver, infectious, and respiratory problems) and (ii) potential interventions to eliminate and minimize precarious employment conditions or at least mitigate its impacts on workers and their families, has increased considerably in recent years (Gunn et al. 2021b; Koranyi et al. 2018; Muntaner et al. 2020; Rönnblad et al. 2019).

\subsection{Rationale for study and contribution to the field}

The aim of the present study is to assess whether the precarious employment conditions of rangers have been examined within recent conservation, criminological, and environmental sustainability publications. Through a preliminary literature search, we identified that the concept of precarious employment is rarely used in relation to rangers yet conditions which are typical of precarity are commonly reported in this literature without being labeled as such. We sought to address this knowledge gap by conducting a scoping review to gather research from around the world and explore a series of interrelated knowledge gaps.

Given the multitude of roles played by rangers in conservation efforts and environmental sustainability, an increased understanding of the ways in which precarious employment affects them could guide the development of suitable interventions and inspire further research that builds on this theoretical framework and measurement of occupational exposures. A focus on rangers' employment and working conditions would also be in alignment with the ongoing sustainable development agenda promoted by global institutions such as the International Labour Organization (ILO), which view decent work as a way of stimulating economic growth, fighting poverty, and reducing disparities (International Labour Organization 2018). The need for such research is further supported by the recent worldwide economic crisis triggered by the COVID-19 pandemic, which brought increased attention to the vulnerability to infection of workers in precarious employment, and the range of severe short and long-term consequences these workers are likely to experience (Matilla-Santander et al. 2021).

Importantly, we suspect that the impacts of the precarity of ranger employment conditions may extend beyond the well-being of the rangers themselves. Rangers who do not have adequate employment security, benefits, rights, supports, and protections may be limited in their ability to sufficiently carry out their duties, protect biodiversity, and support local communities. They may also be more susceptible to misconduct and corruption, including being drawn into the illegal wildlife trade (Belecky et al. 2021). Improving the employment conditions of rangers is especially critical in biodiversity hotspot regions, and regions with high species richness and endemism, where insufficient efforts to protect wildlife may have global repercussions. For these reasons, research is needed to understand the severity of precarity in ranger employment around the world, and how best to address this occupational health risk.

\subsection{Scoping review questions}

Our review addressed the following questions:

Q.1 How is precarious employment conceptualised with regard to rangers?

Q.2 How do the precarious employment conditions of rangers differ geographically?

Q.3 Which of the various aspects of precarious employment conditions of rangers have been examined in the literature?

Q.4 How does precarious employment impact the mental and physical health of rangers?

Q.5 What are the consequences of not improving the employment conditions of rangers?

Q.6 What can be done to improve the employment conditions of rangers?

\section{Material and methods}

Our scoping review protocol was developed using the methodological framework put forth by Peters et al. (Peters et al. 2020). The PRISMA 2009 flow diagram (Fig. 1) is used to illustrate the article selection process and the specifics related to source selection, duplication, inclusion/exclusion and full-text review (Moher et al. 2009).

\subsection{Eligibility criteria}

\subsubsection{Population}

The review includes publications focused on rangers and synonyms (e.g., park warden, conservation officer, forest guard, etc.) and excludes publications focused on other conservation or law enforcement workers (e.g., police officers, military officers referred to as rangers in the American military context, wildlife researchers, road ranger vehicle drivers, volunteer wildlife scouts, volunteer conservationists, etc.).

\subsubsection{Concept}

We included publications focused on precarious employment. To qualify for inclusion, a publication had to either specifically mention the term precarious employment or explore any of the following four dimensions of precarious 
Fig. 1 Article selection process displayed using the PRISMA 2009 flow diagram guide provided by Moher et al. (Moher et al. 2009)

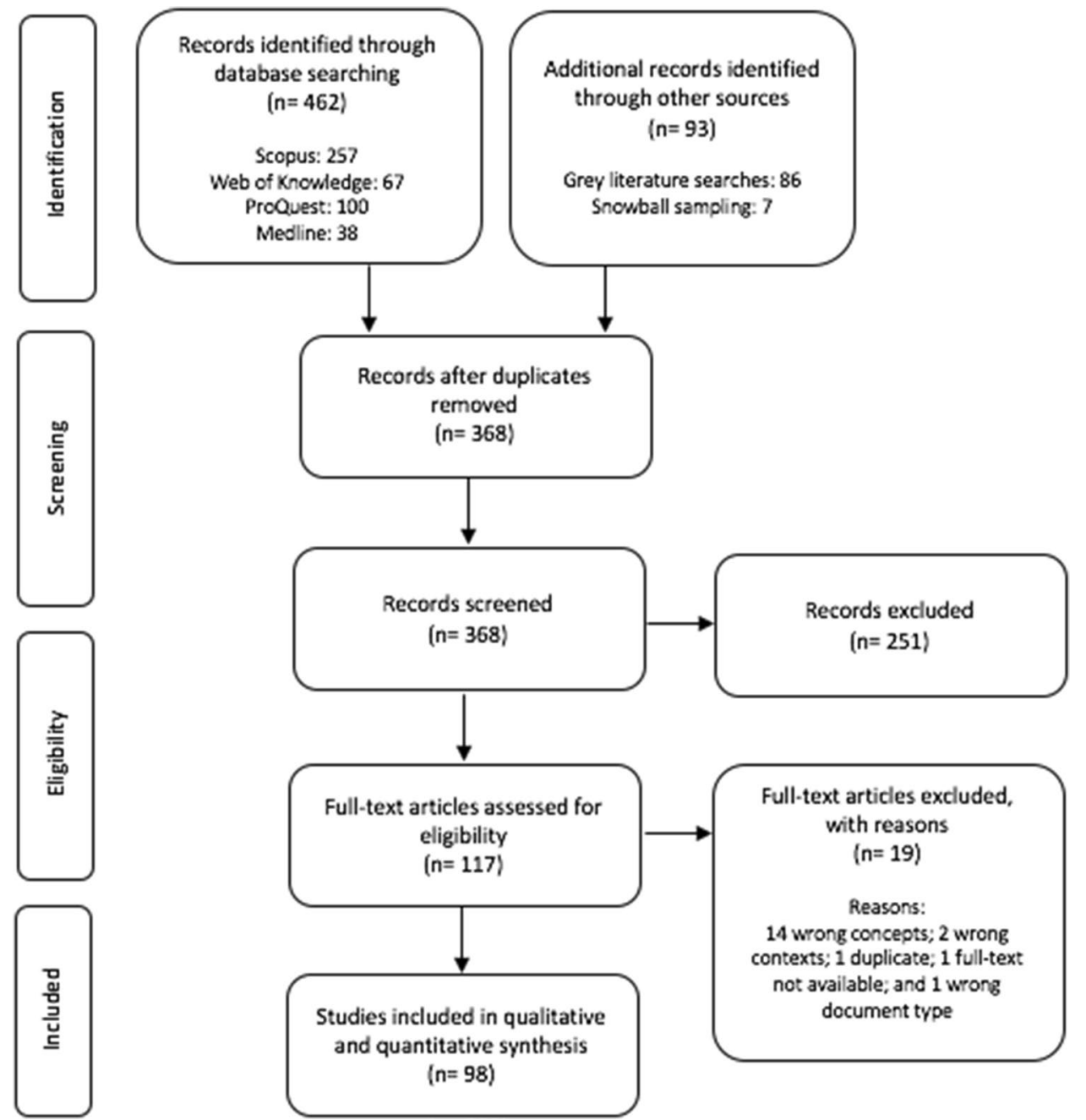

employment: (i) employment insecurity (contractual relationship insecurity, contractual temporariness, contractual underemployment, multiple jobs/sectors); (ii) income inadequacy (income insufficiency and volatility); (iii) lack of rights and protection (lack of unionization, lack of social security benefits, lack of regulatory support, lack of workplace rights); and (iv) problematic working conditions (schedule unpredictability, long working hours, hazardous social and physical work environment). Studies that did not discuss the employment and working conditions of rangers, which focused on the status and protection of wildlife or protected area, rather than discussing the rangers' work, or studies focused on job satisfaction or income level without exploring any of the domains of precarious employment were excluded.

For this scoping review we defined precarious employment as "a multidimensional construct encompassing dimensions such as employment insecurity, individualized bargaining relations between workers and employers, low wages and economic deprivation, limited workplace rights and social protection, and powerlessness to exercise workplace rights"
(Benach et al. 2014) and organized the precarious employment domains building on findings from a recent systematic review of precarious employment definitions and measures (Kreshpaj et al. 2020). In addition to the three dimensions highlighted in Kreshpaj et al. (2020), namely employment insecurity, income inadequacy, and lack of rights and protection, we also focus on problematic working conditions, and, within each dimension, we focus on several themes that are relevant to rangers' employment, such as accommodations and living conditions.

\subsubsection{Context}

We included publications examining rangers working in the context of parks, conservation areas, protected areas, game reserves, wilderness areas, and nature reserves, in any geographical or socio-economic context (e.g., any country regardless of income level, any continent, urban or rural areas, and public or private ownership). Publications focused on rangers who do not work in these contexts were excluded. The context was intentionally kept broad, as we wanted 
to include all possible contexts that rangers may work in. The International Ranger Federation considers rangers to work broadly in "wild areas, historical and cultural sites" and "in protected and conserved areas and wider land- and seascapes" (International Ranger Federation 2020; 2021). Therefore, we did not want to exclude potentially relevant results based on strict categorizations of geographical space.

Outcomes We also included publications that examined the health of rangers and their families (e.g., mental and physical health, well-being, safety, and health equity implications) in the context of their employment and work conditions but excluded publications that focused on the impact of individual characteristics of rangers (e.g., ranger behaviours, choices, coping skills, education and/or training levels, interest in the job, etc.). Other included publications focused on the possible non-health-related consequences of not improving the employment conditions of rangers, such as increased environmental crime, HWC, and corruption. Publications examining such outcomes without discussing at least one domain of precarious employment were excluded.

\subsubsection{Interventions}

We also included publications that discussed either proposed or existing initiatives that could generally improve the employment conditions of rangers. Publications describing initiatives focused solely on leadership training, ranger motivation, or job satisfaction were excluded.

\subsubsection{Types of sources}

English language publications published from January 2000 to June 2021, using any research design (qualitative, quantitative, or mixed-methods), peer-reviewed or non-peerreviewed, including theses/dissertations, press releases, and working papers. Non-English language publications, and English language publications published before January 2000 or after June 2021, books and book chapters, conference abstracts, conference papers and proceedings, trade journals and wire feeds, videos and encyclopedias and reference works were all excluded.

\subsection{Search strategy}

We selected four comprehensive and interdisciplinary scholarly databases and ran a search query on these databases which resulted in 462 records, as follows: Web of Knowledge $(n=67)$, Scopus $(n=257)$, Medline $(n=38)$, and ProQuest $(n=100)$. We also identified grey literature reports $(n=86)$ posted on the websites of relevant organizations and ranger associations. Our list of organizations included: African Wildlife Foundation, African Parks Conservation, Defenders of Wildlife, EcoAmericas, Environmental
Investigation Agency, European Ranger Federation, Freeland Foundation, Game Ranger Association of Africa, Global Environment Facility, Global Initiative, InSight Crime, IFAW, International Institute for Environment and Development, International Labour Organization, International Ranger Federation, International Union for Conservation of Nature, OECD, PANORAMA Solutions, People not Poaching, Ranger Federation of Asia, The Thin Green Line Foundation, TRAFFIC, UNEP, USAID, Wildlife Conservation Society, World Animal Protection, World Wide Fund for Nature. In addition, we searched for online publications from members of the International Ranger Federation that had websites.

The search query consisted of terms identified by the authors to describe rangers, the concept of precarious employment and its domains, and possible outcomes. The search strategy was tailored for each academic database and each reviewed website. A sample search strategy, used for the Web of Knowledge database, is included in the Supplementary Information section (Table S1). We then used snowball sampling of the reference list publications to identify additional citations and possibly relevant papers.

\subsection{Study selection}

The search results were imported to Covidence, the online systematic review collaborative platform, and de-duplicated. In Covidence, every paper was first screened by its title and abstract by at least two members of the author team. An initial pilot test was conducted, and a screening guidance table was created and used to ensure consistency of the inclusion/exclusion decisions among reviewers. The full texts of articles included at the title/abstract screening stage were reviewed and further screened into 92 eligible publications. The review of reference lists of included studies resulted in 7 additional relevant papers, of which 6 were eligible for inclusion in our final results. Hence, the total number of papers included in our scoping literature review was $n=98$ (see Fig. 1 for details).

\subsection{Data extraction}

The Covidence platform was used for the full-text screening stage, conducted independently for each study by two reviewers, and any discrepancies were resolved through discussions among reviewers. An Excel spreadsheet data extraction form was developed and used for this review, to enable the compilation of all extracted data into one document. The extraction categories included details related to each study's author(s), title, year of publication, country/ geographical area covered, as well as specific details relevant to each review question. An initial pilot of the data 
extraction tool was conducted by members of the review team and tailored accordingly.

\subsection{Data analysis and presentation}

Given the exploratory nature of this scoping review, analysis did not include a critical appraisal component. The findings are presented using a combination of text, graphs, and other visuals.

\section{Results and discussion}

\subsection{How is precarious employment conceptualised with regard to rangers?}

We found that, overall, there has been little empirical research on the employment conditions of rangers over the past 21 years, although the number of studies has been rising over time, especially in the grey literature (Fig. 2). In addition, only 2 of the 98 papers included in this review used the term "precarious," yet all papers discussed at least one dimension of precarious employment, although very rarely referring to it from this perspective. For example, Thakholi (2021) conceptualised the precarious employment of rangers using concepts and terms such as low-skilled jobs, gigs and lack of contracts, low income, racial divides in labour conditions, social deprivation, and the lack of rights and protection. The second publication to mention the concept of precarious employment with regard to rangers was a news report by the European Ranger Federation (European Ranger Federation 2018). This publication detailed the story of a Spanish ranger who was almost killed after being attacked by an axe-wielding cattle-herder, pointing to existing limitations of rangerrelated legal frameworks and the need for state-level legislation to improve the safety of rangers (European Ranger Federation 2018).

These findings reveal that the construct of precarious employment is very rarely used in the literature on rangers and, instead, various employment conditions affecting the health and well-being of workers are usually studied separately, as will be discussed in more detail in Sect. 3.3. Failing to account for all employment conditions affecting workers and/or studying these conditions in isolation makes it difficult to (i) accurately measure the impact of precarious employment conditions on health, (ii) understand the mechanisms of interaction between such conditions and health outcomes, and (iii) identify relevant and sustainable solutions to eliminate or minimize precarious employment. This identified gap suggests that conservation and wildlife law enforcement researchers would likely benefit from more interdisciplinary collaborative research to better understand the consequences of precarious employment on ranger's health and on efforts to protect biodiversity, as well as possible ways to improve the employment conditions of rangers and other conservationists.

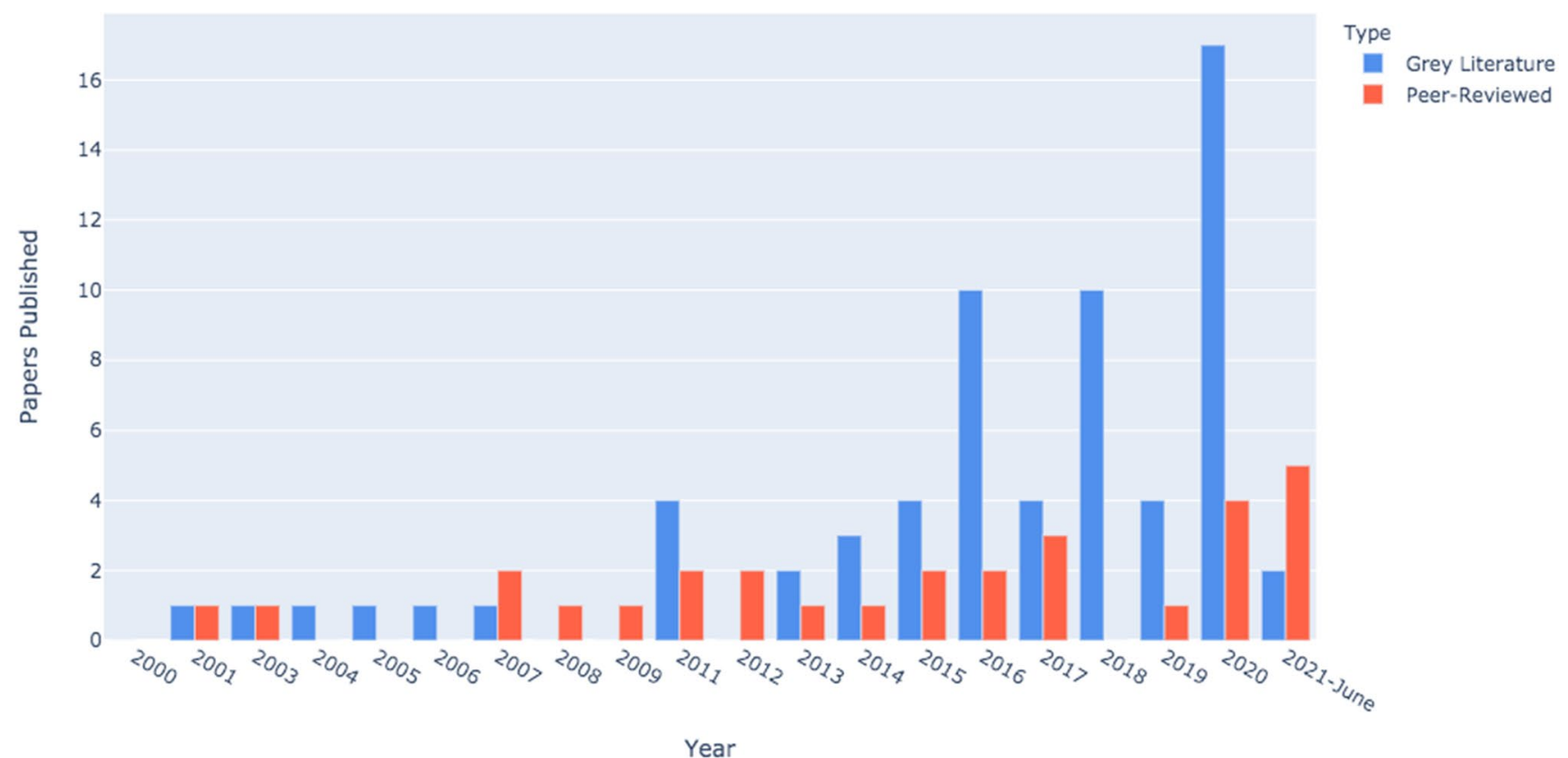

Fig. 2 Publication trends on topics related to the precarious employment conditions of rangers, January 2000-June 2021 ( $n=98)$ 


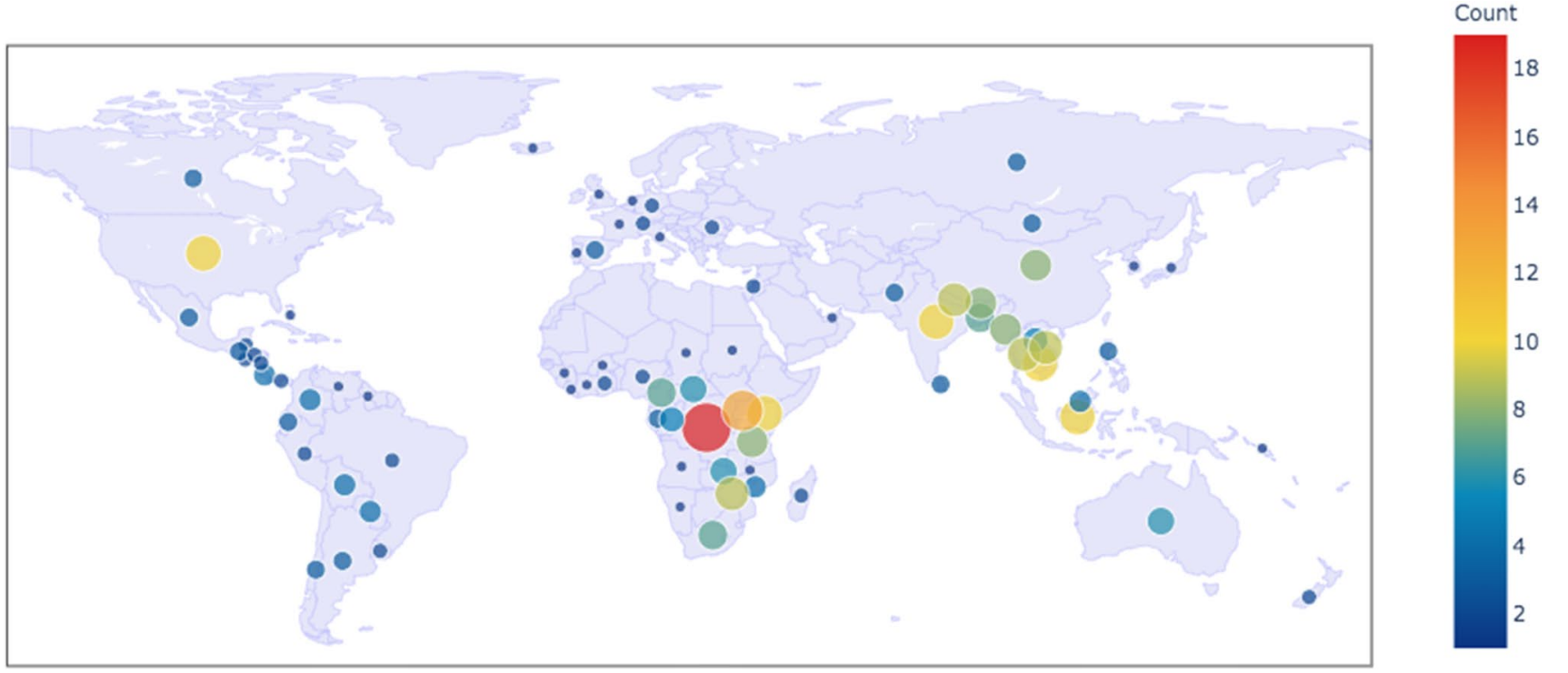

Fig. 3 Global distribution of English language publications on topics related to the precarious employment conditions of rangers, by country, January 2000-June $2021(n=98)$

\subsection{How do the precarious employment conditions of rangers differ geographically?}

Studies on the precarious employment conditions of rangers have been conducted in nearly every major geographic region (Fig. 3) and in 84 countries in total. Hotspot regions for research on ranger precarity include Southern, Eastern, and Central Africa, and South and Southeast Asia. In particular, the Democratic Republic of the Congo (DRC; $n=19$ ) received the most reporting on precarious employment of rangers, particularly in Virunga and Garamba National Parks. Other frequently mentioned countries include Uganda $(n=13)$, Cambodia $(n=10)$, India $(n=10)$, Indonesia $(n=10)$, Kenya $(n=10)$, United States $(n=10)$, Nepal $(n=9)$, Thailand ( $n=9)$, Vietnam $(n=9)$, Zimbabwe $(n=9)$, Bhutan $(n=8)$, China $(n=8)$, Myanmar $(n=8)$, and Tanzania $(n=8)$. Figure $4(\mathrm{a}-\mathrm{g})$ summarises how much attention has been paid to each specific theme within four dimensions of precarious employment, by major world region. Regionspecific examples will also be discussed below throughout Sect. 3.3.

\subsection{Which of the various aspects of precarious employment conditions of rangers have been examined in the literature?}

\subsubsection{Employment insecurity}

Twelve papers explicitly discussed employment insecurity aspects. A large survey on the working conditions of rangers found that over $23 \%$ had non-permanent/ temporary contracts (World Wildlife Fund 2019) while regional reports recognized that $35 \%$ of rangers in Central America (World Wildlife Fund 2018a) and 38\% of rangers in Asia (World Wildlife Fund 2016b) were temporarily employed. This is important as rangers that are on short-term contracts are likely being de-prioritised for equipment and training as a result (Singh et al. 2020). Furthermore, 38\% of countries surveyed in the World Wildlife Fund's (WWF) Ranger Insurance Report employed rangers on temporary contracts without providing employment-related insurance coverage (World Wildlife Fund 2016a). Not surprisingly, the COVID19 pandemic has reportedly exacerbated the contractual relationship insecurity of rangers across various regions, as the halt in tourism activities has diminished the primary source of funding for rangers and conservation efforts in many countries (International Labour Organization 2020). Many rangers were forced to reduce work activities, or stop them entirely, including anti-poaching patrols and community outreach (International Union for Conservation of Nature 2021). In addition, $20 \%$ of rangers lost their jobs due to budget cuts as a result of the pandemic (International Union for Conservation of Nature 2021).

Several studies mentioned that rangers are often underemployed and, generally, lack opportunities for career advancement (Moreto 2015; World Wildlife Fund 2016b, d, 2018b). In some cases, rangers reported that the few promotions available were unfair and offered based on "personal biases resulting in favouritism, tribalism and nepotism" (Moreto 2015). Rangers may also be unpredictably transferred to new outpost stations for irregular and uncertain periods of time (Spira et al. 2019). In addition, the average duration for 

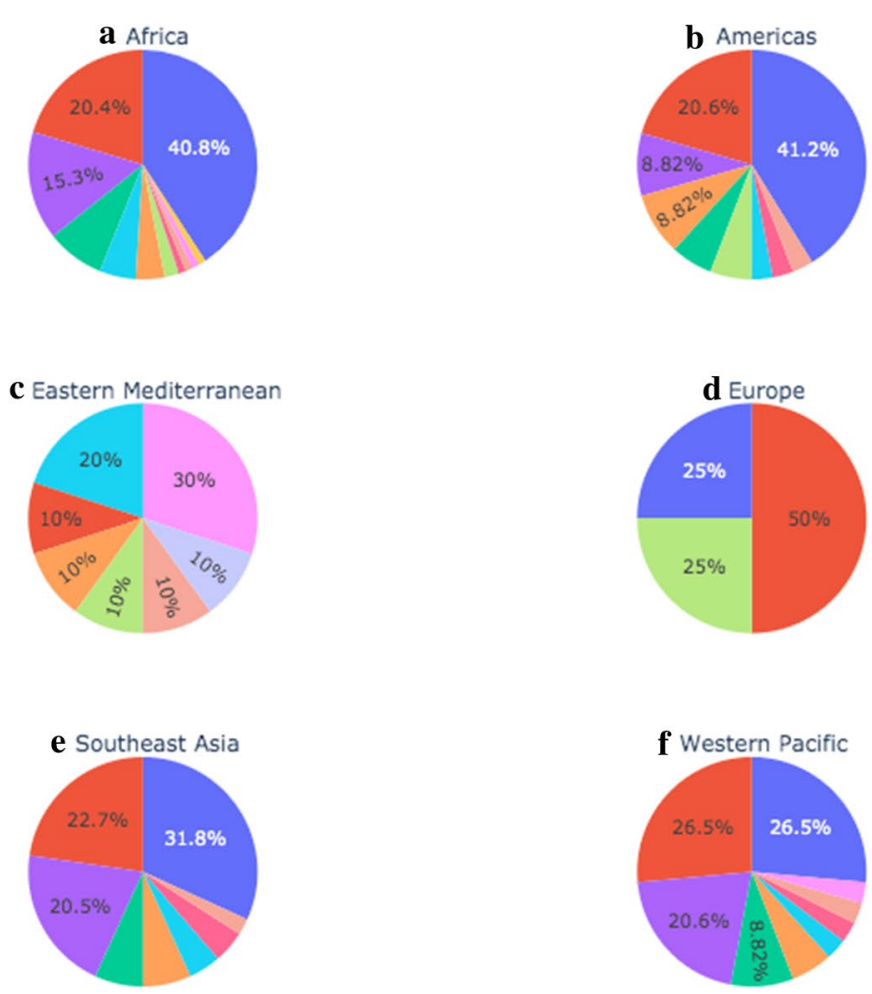

Hazardous Social \& Physical Work Environment

Lack of Workplace Rights

Lack of Social Security Benefits

Income Level

Income Volatility

Long Working Hours

Contractual Temporariness

Lack of Regulatory Support

Lack of Unionization

Contractual Relationship Insecurity

Multiple Jobs/ Sectors

Contractual Underemployment
Fig. 4 a-g Regional distribution (\%) of English language publications on topics related to the precarious employment conditions of rangers, January 2001-June $2021(n=98)$, using the World Health Organi- sation's categorization of regions (the African Region, the Region of the Americas, the Eastern Mediterranean Region, the European Region, the South-East Asia Region, and the Western Pacific Region) postings of wardens is short (3-4 years), which is too short for them to become thoroughly familiar with the park situation and become effective at their job (Aung 2007). Moreover, a small number of rangers held other paid jobs besides being a ranger (World Wildlife Fund 2018b, 2019).

\subsubsection{Income inadequacy}

Our results suggest that rangers experience income inadequacy frequently, as this was emphasised in 30 papers (31\%). The most commonly discussed form of income inadequacy was low income level. Many studies found that rangers did not feel they were paid a fair wage, especially given the dangers associated with the job (Belecky et al. 2021; International Union for Conservation of Nature 2011a; Moreto et al. 2019; Ogunjinmi et al. 2008; World Wildlife Fund 2018b, 2019). Rangers may not even be able to "bring some soap home" after completing an exhausting and hazardous field mission (Poppe 2012). Rangers are typically paid less than other law enforcement officers, despite facing life-threatening conditions, such as armed intruders and dangerous wildlife in isolated contexts. COVID-19 has led to further reductions in pay and reduced salaries for rangers globally (Singh et al. 2021b). Researchers found that, often, rangers stay in their jobs despite receiving insufficient salaries because they feel they have limited employment options, and, consequently, could be exploited by their employers, particularly in private nature reserves (Thakholi 2021).

The other major aspect related to income inadequacy is income volatility. Eleven studies described how rangers received irregular, late, and devalued payments, which indicate the presence of employer abuse and exploitation, which is illegal in many countries. Thirty three percent of rangers surveyed in 28 countries were paid late at least once in the past 12 months, while $7 \%$ of rangers had their payment withheld for over 2 months, and $4 \%$ had their salaries canceled entirely (World Wildlife Fund 2019). For example, Burkinabé rangers are paid low wages that are based on a meritocratic system (rewards) and occasional payments, rather than a regular salary (Poppe 2012). Income volatility is linked to other aspects of precarious employment, such as normalization of overtime, as rangers sometimes are not paid beyond regular hours, even after working 12-h days in the bush (Poppe 2012; Ranger Federation of Asia 2016). Income volatility is another dimension of precarious employment that has been exacerbated by COVID-19 (Global Environment Facility 2020a; International Union for Conservation of Nature 2021; Singh et al. 2021b). In addition to increasing an individual's risk of experiencing poverty, the combination of low income and high income volatility can have direct, 
severe implications for rangers' health, well-being, motivation, good governance, and ability to prevent wildlife crime (see Sects. 3.4 and 3.5).

\subsubsection{Lack of rights and protection}

3.3.3.1 Lack of social security (social benefits and protection) Our results suggest that there is a severe and widespread lack of workplace rights and protections available for rangers, as this was outlined in $54 \%$ of the included studies $(n=53)$. A common theme identified was a lack of social security benefits. According to the literature, the majority of rangers lack health insurance, life insurance, long-term disability coverage, and workplace pensions, meaning that if a ranger has a work-related injury or even death, there would be no support available (Ranger Federation of Asia 2017; Singh et al. 2021a; Spira et al. 2019; World Wildlife Fund 2016a, e, 2018b, c). Rangers also lack medical support when dealing with illnesses that are common in their line of work (Moreto et al. 2015; Ranger Federation of Asia 2020). The severity of the situation was well-captured by Stellar (2017), who pointed out that ranger employment conditions and the lack of social support are contrary to Article 25 of the Universal Declaration of Human Rights, which states that "everyone has the right to a standard of living adequate for the health and well-being of himself and of his family, including... necessary social services, and the right to security in the event of unemployment, sickness, disability, widowhood, old age or other lack of livelihood in circumstances beyond his control" (United Nations General Assembly 1948).

At a global level, the Ranger Insurance Report (World Wildlife Fund 2016a) found that rangers have no health insurance coverage in $20 \%$ of the countries surveyed; no life insurance coverage in $35 \%$ of countries; and no longterm disability coverage in $45 \%$ of countries. In the most extreme, yet unfortunately not uncommon example, when rangers are killed while on the job, their families may be left vulnerable to a life in poverty (World Wildlife Fund 2018c). Government welfare or insurance is often inadequate or nonexistent for the partners, parents and children of rangers who die on the job (The Thin Green Line Foundation 2020a). Interestingly, some studies reported that the available social supports are less than the support that police, military, coastguards, and firefighters receive, despite rangers facing the same or higher degree of risks and hazards (World Wildlife Fund 2016a, e).

These inadequacies are prevalent across multiple regions, although Africa's rangers in particular may receive the least social support (Game Rangers Association of Africa nd; World Wildlife Fund 2016a, 2019). Unsurprisingly, given both the importance and the dangerous nature of rangers' work, advocacy efforts promote at least full insurance coverage for all rangers (World Wildlife Fund 2019).

Rangers generally lack access to regular leave days, which can include sick leave, domestic leave, bereavement leave, and parental leave (World Wildlife Fund 2016d). The 2019 global Life on the Frontline report found that $45 \%$ of rangers do not get paid sick leave and $31 \%$ do not get paid annual leave (World Wildlife Fund 2019). Additionally, 77\% of rangers do not receive overtime compensation and $78 \%$ of rangers are denied extra pay for dangerous work conditions (World Wildlife Fund 2019). Though lacking research attention, there are several gender dimensions concerning the lack of social support for rangers, particularly for rangers who are mothers. For instance, female rangers have reported that they have a higher burden of childcare and constantly feel worried about their children's supervision and well-being while out on patrol, especially during patrol trips which can last several weeks (Kubania 2019). Article 25 of the Universal Declaration of Human Rights also states that "motherhood and childhood are entitled to special care and assistance" (United Nations General Assembly 1948).

However, pregnant rangers may feel they have to continue going on multi-week patrols throughout the majority of their pregnancies due to the lack of support available (World Wildlife Fund 2019).

3.3.3.2 Low Levels of Unionization We found only four papers that explicitly discussed the issue of unionization. Nearly half of all rangers in two global surveys responded that they did not have access to a union or similar body that could represent and collectively bargain on behalf of rangers (World Wildlife Fund 2018b, 2019). A study in South Africa found that although many park employees were in fact members of a union, there was little confidence in the effectiveness of unions (Thakholi 2021). In addition, given the size of protected areas, limited transportation, and amount of time rangers spend on the job, it can be difficult for them to exercise their right to organize (Thakholi 2021). More research is needed to understand the accessibility of unions to rangers, and the means by which unions can better empower rangers to negotiate for better working conditions. Effective unions may be able to increase rangers' participation in work-related decision-making, and advocate for improved working conditions, including the conversion of temporary to permanent contracts, work accommodation standards, payment for working overtime, and training opportunities (Queensland Ranger Association 2005).

3.3.3.3 Lack of regulatory support (regulatory protection, labour policy) Nine studies described a lack of regulatory support for rangers. Though there are numerous policies and laws in most countries to provide regulatory protection for workers in general, researchers found that these are often not 
applied or enforced in the context of rangers. As described in one study, the local labour department rarely conducted inspections, and employers avoided disputes about contracts, overtime or salaries by simply not showing up to meetings (Thakholi 2021). This is contrary to the ILO's Labour Inspection Convention (1947), specifically Convention No. 81 (World Wildlife Fund 2019), which stipulates that workplaces should be inspected as necessary to ensure that legal provisions relating to conditions of work and worker protection are enforced by labour inspectors (International Labour Organization 1947). The ILO provides numerous additional relevant legal instruments that can support decent working conditions for rangers, such as the Convention on Labour Relations in the Public Service; Tripartite Consultation Convention (1976); Freedom of Association and Protection of the Right to Organise Convention; FortyHour Week Convention, Protection of Wages Convention; and the Occupational Safety and Health Convention (World Wildlife Fund 2019). However, a survey of ranger working conditions conducted in 14 ILO member countries, identified that most countries had not ratified numerous important ILO conventions (World Wildlife Fund 2019).

\subsubsection{Lack of workplace rights}

3.3.4.1 Lack of equipment and training opportunities A lack of workplace rights for rangers was discussed in 44 of the papers (45\%). One of the most common conditions of precarious employment that emerged from the literature is the lack of sufficient equipment and training opportunities for rangers to safely and effectively perform their required duties (People Not Poaching 2020; Ranger Federation of Asia 2016; Robbins 2019; World Wildlife Fund 2016a, b, d, 2018a). Rangers do not always have access to necessary protective gear, binoculars, rations, first aid kits, or communication devices (Moreto 2015; Ogunjinmi et al. 2008). Ogunjinmi et al. (2008) found that $98 \%$ of rangers surveyed felt that patrol equipment, including fuel for vehicles, was inadequate or in poor condition. In addition, a global survey by Singh et al. (2020) found that the majority of rangers did not feel they were provided with proper equipment or amenities such as mosquito nets and repellent, boots, tents, compasses, GPS technology, clean drinking water, flushing toilets, and bedding facilities (Singh et al. 2020; World Wildlife Fund 2018b, 2019). Therefore, the right to be protected from danger by having access to needed equipment is not being met in many locations globally (The Thin Green Line Foundation 2020b). Rangers can even struggle to obtain the proper uniforms for their job (Cochrane 2020) and many rangers have to buy their own equipment with their own money (World Wildlife Fund 2019), which as previously discussed is problematic given the severe income inadequacy of rangers. Finally, rangers who are not provided with adequate personal protective equipment and come into close contact with wildlife are at high risk of contracting insect-borne or zoonotic diseases, such as COVID19 (International Labour Organization 2020).

While basic job training may be provided for rangers, such as physical patrol activities, some rangers reportedly do not receive any training for the job at all (The Thin Green Line Foundation 2018). Even basic patrol training is insufficient in situations where rangers commonly work with local communities on the human dimensions of wildlife management (Aung 2007). Furthermore, although wildlife and forestry training is important, training on ranger ethics and duties to the public are often forgotten (Belecky et al. 2021) and rangers do not typically receive training for specialised tasks that are still important aspects of their role, such as intelligence gathering, engaging communities, and the social aspects of dealing with HWC (Singh et al. 2020). Insufficient training can also be directly harmful to the physical health of rangers, such as when rangers are not trained in first aid, infection control, or to understand and respond to heat stress and strain (Krake et al. 2003). Rangers may not be trained in basic unarmed self-defence and effective arrest techniques (Stellar 2017). Similarly, rangers are often not supplied with less-harmful gear to handle confrontations with offenders, such as batons, handcuffs, tasers, and eye irritants (Stellar 2017). The high risks of the job due to inadequate training and equipment (such as encountering armed intruders and exposure to infectious diseases) are amplified by the fact that few receive fair insurance (World Wildlife Fund 2018c). In short, the insufficient equipment and training of rangers can lead to failed operations, serious injuries, and death (Ranger Federation of Asia 2017).

3.3.4.2 Discrimination and harassment While discrimination and harassment are acknowledged within several definitions of precarious employment (Kreshpaj et al. 2020) but not all, their inclusion can provide valuable insights. The discriminatory treatment of rangers in lowand high-income countries alike may be rooted in systems of racial/ethnic and gender-based inequalities. For example, Thakholi (2021) described numerous ways in which rangers in South Africa have experienced racially discriminatory treatment at work, while Gilpin (2016) investigated the long-standing culture of machismo which translates to a hostile work environment for women in the United States National Park Service. Rangers may be particularly vulnerable to workplace discrimination given the numerous compounding precarious employment conditions discussed already, in addition to their geographic isolation. Employers of rangers may reinforce inequalities on the basis of race, age, sex, religion, sexuality, and nationality, by allowing the differential treatment of employees in terms of income level, conduct, verbal and 
physical harassment, opportunities for advancement, and unwanted sexual advances. Between 13 and $15 \%$ of rangers surveyed in WWF's 2019 global survey reported having experienced verbal abuse, bullying, and harassment from co-workers and supervisors while on duty (World Wildlife Fund 2019). Many female rangers across the United States have experienced on the job sexual harassment and assault (Gilpin 2016), while the majority of male rangers surveyed in Yankari Game Reserve reported often being mistreated by supervisors (Ogunjinmi et al. 2008). Our results suggest that rangers do not have sufficient mechanisms in place nor is workplace legislation enforced sufficiently to protect them when they are mistreated on the job. In addition, rangers clearly lack sufficient whistleblower protection protocols, as nearly $60 \%$ felt they would be concerned for their safety if they reported corruption in the workplace (World Wildlife Fund 2019). Furthermore, the increased masculinization of ranger work, gender-segregation of roles, and inadequate assessment of women's needs in terms of working conditions and provisions, are also among the structural barriers inhibiting gender balance in the ranger workforce (Seager et al. 2021).

3.3.4.3 Unjustifiable dismissal Job insecurity and a lack of workplace rights and trust is commonly reported in the literature. Rangers may fear wrongful dismissal if they make a mistake on the job (Moreto 2015). In some cases, rangers have to face stereotyping, prejudice, discrimination, and possible unjustifiable dismissal, as their superiors may treat them with suspicion if they come from a community with high levels of illegal wildlife activities (Thakholi 2021). As a result of this "toxic mistrust", some organisations are frequently subjecting rangers to taking polygraph tests (Thakholi 2021). During a lengthy controversy in the early 2000s, in which Parks Canada rangers advocated for the right to carry sidearms to protect themselves while performing law enforcement duties, the issue became so sensitive that rangers reportedly feared losing their jobs if they spoke up, or being transferred to an undesirable, remote station (Ko 2001). These challenges associated with a lack of workplace rights, in addition to the low and volatile funding of parks organisations, has meant that many rangers around the world experience a high sense of job insecurity. The high job insecurity of rangers has been evidenced by the number of rangers who have lost their jobs since the start of the COVID-19 pandemic. As reported by Singh et al. (2021b) "nearly 20\% of rangers reported that colleagues had been laid off from their jobs due to COVID-19 related budget cuts. More than a third of all rangers in Central America and Caribbean countries reported being laid off, closely followed by South America and Africa. In Asia, the figure was one in five and in Europe less than one in ten."
3.3.4.4 Accommodation and living conditions Although living conditions are not typically discussed in the context of employment conditions, they are an important consideration since many rangers live in accommodations provided by their employers in remote stations in protected areas, with no other housing options. Ranger outposts often lack basic infrastructure to adequately support and accommodate the field rangers (Kuvawoga 2020; World Wildlife Fund 2018a). For example, prior to a recent intervention, rangers in Bwindi Mgahinga Conservation Area did not have access to decent housing and flush toilets (Uganda Wildlife Authority 2020b). Similarly, Quiçama National Park rangers have slept on the ground in metal huts (Global Environment Facility 2020b), and Russian nature reserves can also lack necessary facilities for rangers, and some may not even have offices (Safonova 2007). Living conditions for rangers can be old, dilapidated, and highly inequitable, even within the same protected area (Moreto 2015). For instance, Moreto (2015) found that while some outposts had fully serviced units, others were simple mud or uniport huts, and often without access to utilities, amenities, or clean water. Ranger outpost structures can be uncomfortably small, have leaky roofs, and have holes in the walls that invite insects and snakes (Nyagah 2019). These often poor ranger accommodation conditions have been exacerbated by the COVID19 pandemic, as travel restrictions have made it more difficult for suppliers to travel to remote stations and restock food supplies (Global Environment Facility 2020a). Private sector tour operators that previously assisted rangers with patrol rations, fuel, and vehicle services, have reduced or stopped their support (Kuvawoga 2020).

\subsubsection{Working conditions}

3.3.5.1 Long working hours and demand for overtime Eleven papers indicated that rangers across all geographic regions work extremely long days and nights (Moreto 2015; Singh et al. 2021b; Stellar 2017). The global average of working hours of rangers is $72 \mathrm{~h}$ per week, with 33 of those hours worked at night between the hours of $6 \mathrm{pm}$ and 6am (World Wildlife Fund 2018b, 2019). The majority of rangers often have to work overtime (Kubania 2019), and most are not compensated for their overtime hours (World Wildlife Fund 2018b, 2019). This trend is particularly notable in South Asia and Africa (World Wildlife Fund 2019). Rangers also often have to sacrifice sleep during night patrols (Global Environment Facility 2020a; Moreto 2015). The overtime demands of the job and the feeling of always being on the job have been linked to high work-related stress levels in rangers (Ledford et al. 2021). Extended patrol trips are also made more precarious given the lack of equipment, transport, communication devices, and the added challenge 
of making camp and finding water (International Union for Conservation of Nature 2014b; Stellar 2017).

\subsubsection{Hazardous social and physical work environ-} ment Violence The most frequently reported dimension of precarious employment of rangers is the hazardous social and physical work environment. We found this topic discussed in $74 \%$ ( $n=73)$ of the papers reviewed, focusing on low- and high- income countries alike. Many studies stressed that rangers generally face a violent work environment, as they are potentially faced with armed poaching, logging, and fishing gangs, who may attack rangers pre-emptively or in retaliation to ranger actions (African Parks 2020; Athanas 2015; Environmental Investigation Agency 2014; International Union for Conservation of Nature 2011b, 2014a; Shanahan 2013; Wildlife Conservation Society 2018; World Wildlife Fund 2016b, d). Encountering armed resource extractors can quickly turn dangerous if they respond violently to being approached, and this often results in shootouts that can be lethal to both the rangers and the offenders (African Parks 2015, 2016; African Wildlife Foundation 2003, 2006; ITV News 2016; Margaryan 2013; Uganda Wildlife Authority 2020d). In addition to armed environmental crime offenders, rangers may frequently have to deal with (i) drug cartels that operate within protected areas, (ii) people who commit violent offences such as homicides and rape, and (iii) non-state militias and rebel groups, and often do so while working in isolation with no backup (African Parks nd; Environmental Investigation Agency 2014; Global Conservation 2016; Mararv 2015). Wildlife crime is increasingly reported to converge with other types of serious and organised crime activities thus, further exacerbating the precarity of ranger work (Anagnostou 2021; Anagnostou and Doberstein 2021). As a result, rangers are commonly victims of assault, murder, vandalism of property, or home arson, as well as threats and violence directed towards their families (Cárdenas 2020; International Union for Conservation of Nature 2021; Queensland Ranger Association 2004; World Wildlife Fund 2016b, 2018a). For instance, an Indonesian ranger reported been assaulted by poachers on multiple occasions and having his family house burned down due to his efforts to stop illegal encroachment (Global Environment Facility 2020a). These threats are intensified for rangers working in locations with political instability and armed conflict (Kubania 2019; Wildlife Conservation Society 2016). For example, in Garamba National Park, rangers have historically had to become a heavily militarised force to protect wildlife, as they had to prevent illegal resource extraction from "opponents with assault rifles, belt-fed machine guns, and rocket-propelled grenades" (McConnell 2018). These opponents have in some cases been part of corrupt state militaries, non-state armed groups, and wellequipped elephant poachers and cattle herders (McConnell
2018). Similarly, coca cultivation, drug trafficking, illegal gold mining, illegal logging, and illegal wildlife hunting in Colombia, has attracted at least 17 armed groups to the country's national parks (Robbins 2019), all enhancing the threat posed to rangers. We recognise that the over-militarisation of the ranger workforce can exacerbate inequalities in marginalised rural communities and increase the risk factors for wildlife crime, and instead stress the importance of reducing the precarity of ranger employment, while improving community-ranger relations (see Sect. 3.6).

Environmental factors Although environmental factors are not commonly included in research on employment conditions, they are an important consideration since many rangers face dangerous encounters with wildlife (such as aggravated megafauna, stinging insects, or venomous snakes, insect-borne or zoonotic disease exposure, and harsh weather conditions, such as temperature extremes Big Life Foundation 2018; International Union for Conservation of Nature 2020; Krake et al. 2003; United Nations 2018; World Wildlife Fund 2016b, d, 2018a). Additionally, rangers have to conduct foot patrols over large areas of challenging terrain and with limited access to water (Moreto 2015) and they may work in a wide variety of vast rugged landscapes, and outdoors in the rain, lightning, snow, and high winds (Eliason 2011). Furthermore, support and backup from other rangers, other law enforcement services, and emergency medical care can be hours away and, to worsen matters, many rangers lack any access to communication devices during patrols, which increases the already high risks of the job (World Wildlife Fund 2019). Working in remote areas and often alone without the ability to communicate, leads to many occupational risks for rangers; many have died in motor vehicle accidents, animal attacks, drownings, while fighting forest fires, and several of them succumbed to the COVID-19 virus (DeGroff 2021; The Thin Green Line Foundation 2020b). The lack of communication is a particularly urgent concern in South Asia, where roughly half of rangers surveyed reported never having access to communication devices (World Wildlife Fund 2019). In addition to wildlife, weather, terrain, and isolation, rangers are at high risk of contracting vector-borne, water-borne, and zoonotic diseases (see Sect. 3.4.2).

\subsection{How does precarious employment impact the mental and physical health of rangers?}

\subsubsection{Mental health}

Given the countless risks and dangers involved in being a ranger, as well as the threats to rangers' families, fellow rangers, local community members, and to the wildlife that rangers seek to protect, it is not surprising that many rangers experience traumatic events throughout their careers 
(Ledford et al. 2021; McConnell 2018). Despite this, we found only 8 papers that discuss the impact of employment conditions and exposures on the mental health of rangers. Post-traumatic stress disorder, acute stress disorder, and burnout fatigue, have all been mentioned in the literature as a likely reality for many rangers (Moreto 2015; World Wildlife Fund 2018b, 2019). As described in a recent study (Thakholi 2021), "at home and unarmed, [anti-poaching units] and rangers spoke about a persistent sense of anxiety over their safety. At work, they felt safe but constantly worried about their family's safety." Other risk factors for the development of mental health outcomes in rangers are occupational stress and emotional strain as a result of being away from their families (Moreto 2015). Parents, in particular, may feel chronic stress for being away from their children for prolonged periods of time with limited leave (with most of the burden usually falling on female caregivers) (Kubania 2019). Though the distressing and violent incidents that rangers deal with on the job are well-known, more research is needed to understand how this can impact rangers' mental health, how to prevent/ mitigate mental health impacts, particularly with regards to trauma, and how best to support rangers who have developed mental illness and disorders as a result of their work (World Wildlife Fund 2019).

\subsubsection{Physical health}

The previously discussed temperature extremes mean that rangers can experience heat stress and heat-related symptoms (e.g., dehydration, fatigue, nausea, dizziness, light headedness, impaired judgement, and sleep deficits) from performing high physical workloads in high temperatures (Krake et al. 2003). Heat stress is particularly challenging for rangers working in areas where it is difficult to access clean drinking water (Moreto 2015). Injury and illness due to prolonged exposure to cold temperatures is also likely a challenge for rangers working in cold climates, although we did not find any studies that discussed this.

The inadequacy of housing, general lack of equipment such as mosquito nets, and often complete lack of shelter while on patrol, leaves rangers around the world highly susceptible to flea-borne, mosquito-borne, tick-borne, and fly borne diseases (Adjemian et al. 2012; Global Environment Facility 2020a; International Union for Conservation of Nature 2014b; Ranger Federation of Asia 2020). In a case study by Nagy et al. (2016), researchers ran a series of diagnostic tests and medical treatments for a 25 -year-old ranger in Romania who was experiencing abnormalities of behavior, anxiety, visual hallucinations, choreiform, and facial tics. They determined that the ranger had a severe case of exposure to Borrelia (the bacteria that causes Lyme disease) as a result of tick-bites, which are a common occupational risk factors for rangers (Nagy et al. 2016). Rangers are at high risk of contracting Lyme disease, Dengue, Malaria, African Trypanosomiasis (sleeping sickness), and COVID19, to name a few (Ranger Federation of Asia 2020; World Wildlife Fund 2018b, 2019). Studies show that $68 \%$ of African rangers surveyed, and up to $80 \%$ of forest rangers in Vietnam's Bu Gia Map National Park may contract Malaria yearly (Thuy-Nhien et al. 2017; World Wildlife Fund 2019).

The poor sanitation of ranger stations, such as a lack of toilets and sinks (Spira et al. 2019; Uganda Wildlife Authority 2020b), and limited access to clean water is an added risk for the transmission of numerous other infectious diseases (Ranger Federation of Asia 2020). In addition, rangers are susceptible to direct transmission of zoonotic diseases. Transmission can occur through animal bites, or through contact with live animals, carcases, bodily fluids, and feces (Adjemian et al. 2012). This is also a risk for rangers when confiscating illegally caught wild animals. Fifty six percent of rangers surveyed in the Great Smoky Mountains and Rocky Mountain National Parks, particularly those working in law enforcement and rescue, reported contact with animals at work (Adjemian et al. 2012). Stevenson et al. (Stevenson et al. 2015) reported a medical case study of a 28-year-old female ranger in Australia who began experiencing nausea, vomiting, anorexia and generalised abdominal discomfort, fever, respiratory failure, and other symptoms. Her work included park maintenance, including disposing of road-kill animals, which were mostly kangaroos and wallabies (Stevenson et al. 2015). She was diagnosed with Q fever which the authors suggested is likely from the frequent ongoing physical contact with dead wild animals in the course of her work (Stevenson et al. 2015). The numerous risks of injury and illnesses are compounded by the fact that, as previously discussed, many rangers may not have access to sufficient, or any insurance to cover medical treatments.

\subsubsection{Occupational injuries}

Given the challenging social and physical work environment, rangers may experience injuries such as broken bones and other serious bodily injuries (World Wildlife Fund 2018b, 2019), or even death. Regarding assault on the job, Forsyth and Forsyth reported that rangers have been "shot at and missed...shot at and hit...run over with boats and cars... beat up with fists, pipes, tree branches, pieces of lumber, and any other thing someone can pick up, grab, and swing" (Forsyth and Forsyth 2009). The lack of first aid kits and training, and the inability to get fast medical treatment following injuries, may result in otherwise treatable injuries causing irreversible damage or death. Sixty papers $(61 \%)$ in our study outlined assault and death as two clear consequences of rangers' hazardous work environment. For example, rangers in Cambodia have been killed in their sleep by illegal loggers (Newman 2015), while 13 rangers 
were killed by elephants in 2020 (McPherson 2021; Uganda Wildlife Authority 2020a). We identified many other similar stories from numerous countries. In fact, according to the Thin Green Line Foundation, over 1000 rangers have died protecting wildlife in the past decade, and with the escalating risks, roughly 150 rangers are currently being killed each year (Global Environment Facility 2020a; The Thin Green Line Foundation 2020a).

The reported global breakdown of recorded ranger deaths by region from 2009-2019 were: $48 \%$ in Asia, 37\% in Africa, 6\% in North America, 4\% in South America, 3\% Europe, $1 \%$ in Central America, and $1 \%$ in Oceania (World Wildlife Fund 2019). India has had the highest recorded number of ranger fatalities on duty over the last few years, with 46 ranger deaths in 2020 (Belhekar et al. 2020; McPherson 2021). In general, causes of work-related death of rangers have included tetanus, falling boulders and trees, helicopter crashes, motorcycle and automobile accidents, vehicular assault, heart attacks, gunshots, rapid changes in weather, exposure, infection, and accidents while operating heavy machinery, clearing snow, and repairing trails (DeGroff 2021; Eliason 2011). A survey of rangers in Asia, Africa, and Latin America found that the majority had experienced a life-threatening situation while on the job, especially dangerous encounters with wildlife, as well as being threatened by poachers or community members, and about $40 \%$ had been attacked by poachers (Singh et al. 2020). In the United States, rangers reportedly experience more assaults than officers of the Federal Bureau of Investigation, the Bureau of Alcohol, Tobacco, Firearms and Explosives, and the Drug Enforcement Administration (DeGroff 2021).

\subsubsection{Well-being}

Twenty-three papers discussed the compounding effect of a lack of social support and/or supportive relationships, and the negative impacts of employment precarity on rangers' well-being. In particular, emphasis was placed on how limited time with friends and family impacted rangers' wellbeing (Ledford et al. 2021; World Wildlife Fund 2016b, d). The inadequate living conditions for rangers, along with the distance of ranger outposts from schools and public amenities, means that most rangers cannot bring their families to live with them (Moreto 2015; Singh et al. 2020; Thakholi 2021). Some rangers report being stationed at anti-poaching camps for at least 26 days per month, which means they can only spend a maximum of 4 days with their family (and often traveling to their families takes a full day, therefore limiting family time to 3 days only) (Belhekar et al. 2020). Seventy seven percent of rangers surveyed in Africa, $76 \%$ in Asia, and 53\% in Central America see their families fewer than 10 days a month (International Union for Conservation of Nature 2021; World Wildlife Fund 2016b, d). In extreme cases, rangers may be isolated from their families for an entire year (World Wildlife Fund 2016a). When rangers are transferred to protected area stations that are farther away from their home and families, they can perceive these decisions as punishment from management (Spira et al. 2019). COVID-19 lockdowns and travel restrictions have worsened the social isolation of rangers and their abilities to see their families (Kuvawoga 2020).

Rangers may suffer from social alienation, isolation, and work conditions that harm well-being. Many rangers suffer from poor work-life balance and often report that they feel like they are always on the job (Ledford et al. 2021; Ranger Federation of Asia 2016). The remoteness of ranger work means they have limited leisure opportunities and "no respite from the workplace" (Kuiper et al. 2021). The lack of decent housing and low wages for rangers also likely harms ranger well-being (Singh et al. 2021b). Female rangers described work-life balance as being particularly challenging during the COVID-19 pandemic (Singh et al. 2021b). They also reported additional adverse work-related impacts on their well-being such as feelings of anxiety, feeling trapped, being ostracized, receiving hostility from co-workers and supervisors, and poor job evaluations after reporting incidents of sexual harassment/ discrimination (Gilpin 2016). Rangers may feel alienation, lack a sense of belonging, and have a lack of access to social interaction. These factors of social deprivation are especially prevalent in areas where local communities are opposed to conservation efforts, and may treat rangers with hostility (Poppe 2012). In one study, roughly $31 \%$ of surveyed rangers reported being subjected to verbal abuse, bullying, harassment, and threats from community members while on duty in the previous 12 months (World Wildlife Fund 2019). In some cases, a strained relationship between rangers and the community can directly harm ranger health and well-being, as rangers often depend on the local communities for basic needs like water (Belhekar et al. 2020). Rangers may also feel that there is mutual mistrust with community members, and fear reprisals for the activities of their job (e.g., arresting a poacher) (Anagnostou et al. 2020; Moreto 2015). In addition, the isolation and lack of social support while on the job is likely to amplify the feelings of fear that rangers feel (Forsyth and Forsyth 2009).

\subsection{What are the consequences of not improving the employment conditions of rangers?}

\subsubsection{Increased risk for rangers to engage in corruption}

The presence of corruption among rangers was mentioned in 10 papers. Half of these papers focused on countries in Africa, such as Uganda, Cameroon, DRC, and Burkina Faso (African Wildlife Foundation nd; International Union for Conservation of Nature 2011a; Moreto et al. 2015; Poppe 
2012; Spira et al. 2019). Both Southeast Asia and Europe had 1 paper each, focused on Cambodia and Russia, respectively (Newman 2015; Safonova 2007). The 2021 WWF report "Corrupting conservation: assessing how corruption impacts ranger work" considered that "rangers can be both perpetrator and victims of corruption," and acknowledged that there are different social, economic and organisational incentives for rangers to engage in corruption (Belecky et al. 2021).

Income inadequacy was repeatedly cited as one of the main drivers encouraging ranger participation in corruption through accepting bribes from poachers (Moreto et al. 2015; Poppe 2012; Spira et al. 2019). In a 2015 paper by Moreto et al., one ranger explained that since the salary is not adequate, he could be "tempted to receive that bribe to finish my problems at home," while another ranger stated: "if I kill a buffalo, my children can go to school" (Moreto et al. 2015). A report by the International Union for Conservation of Nature (IUCN) compared rangers' work-related revenues with the overall profitability of the illegal wildlife trade industry (International Union for Conservation of Nature 2011a). For example, “assuming a ranger earns US $\$ 50$ a month, an average ten-kilo tusk comes in at US $\$ 17,000$, or 340 times that monthly salary" (International Union for Conservation of Nature 2011a). Rangers expressed that bribe money was put towards necessities such as bills and their children's school fees, and that participation in corruption was done to sustain their welfare (Moreto et al. 2015).

A lack of training on the content of rules and regulations, limited supervision, and the extended periods of time that rangers spend alone at ranger outposts are additional factors contributing to corruption (Moreto et al. 2015). Rangers may take advantage of low levels of supervision to form agreements with poachers and intruders. In Burkina Faso, an arrangement consisted of rangers allowing herders to graze in restricted areas for a period of time and to then warn them of approaching resource managers in exchange for some sort of payment, thus, creating a new source of income for the rangers (Poppe 2012). Corruption was also linked to contributing factors such as low morale, limited motivation, and feelings of unfair treatment. The risk of corruption may further increase through resentment linked to perceived unfairness, which may also negatively impact ranger work efforts (Belecky et al. 2021). One ranger commented that "if rangers are not motivated they will start misbehaving. Looking for money for motivation" (Moreto et al. 2015). Keeping morale and motivation high can be difficult when every level of a ranger's organization may be susceptible to corruption, thus undermining good governance and the efforts made by rangers to protect both wildlife and communities (Belecky et al. 2021).

Corruption can exist at any point in the wildlife crime value chain and can involve and impact rangers, prosecutors, communities, park administrators, and other actors (Belecky et al. 2021). For instance, some rangers in the DRC reported feeling unsafe while conducting their duties due to the risk of detainment, or revenge from arrested individuals, and acknowledged their willingness to accept bribes instead (Spira et al. 2019). Protecting wildlife and communities is especially challenging for rangers when the government is working against them. In Cambodia, two wildlife rangers lost their life fulfilling their government mandate to defend protected areas even though they were fighting against state-facilitated illegal logging (Newman 2015). With little incentive to report corrupt behaviour and weak judiciaries, leading to low conviction rates for wildlife criminals, opportunities for corruption may not be uncommon (Belecky et al. 2021; Dudley et al. 2013).

In contrast to the wealth of evidence that corruption can commonly occur throughout ranger organizations, reporting on corruption and misconduct is not a frequent occurrence. In a global survey, over $50 \%$ of rangers agreed they would be concerned for their safety if they reported another ranger for corrupt and illegal activities (World Wildlife Fund 2018b, 2019). This is a concerning finding, as the fear to speak up allows corruption to grow as a culture within ranger organizations. Organisations must seek to conduct risk assessments for ranger corruption and develop sound protocols to protect informants and whistleblowers (including rangers and members of local communities) so that they can safely report corruption without fear of retaliation (Anagnostou et al. 2020; Belecky et al. 2021).

\subsubsection{Biodiversity protection}

We found 19 papers that mentioned the precarious employment conditions of rangers, as impacting their ability to address wildlife crime or wildlife-human conflict. The geographic distribution of these papers was largely centered on the African region $(n=11)$, including Tanzania, DRC, Nigeria, and Zimbabwe, among others (African Wildlife Foundation 2001, 2020; Atim Nchor et al. 2021; International Union for Conservation of Nature 2017; Kubania 2019; Kuiper et al. 2021; Spira et al. 2019). The remainder of the papers were global $(n=4)$ or focused on the Southeast Asian region $(n=2)$, the Americas $(n=2)$ and the Western Pacific $(n=1)$. None of the included papers focused on ranger employment conditions and species protection in the Eastern Mediterranean or European regions.

Many of the same factors that contribute to corruption in ranger organizations also inhibit rangers' capacity to reduce wildlife crime and HWC, including low pay, under-staffing, and harsh working conditions. The inadequacy of rangers' salaries, and their inability to access the necessary equipment for their job, may lead disgruntled rangers to apply their expertise to committing wildlife crime, or ignoring it, 
rather than preventing wildlife crime (Belecky et al. 2021; Cochrane 2020). Research in Nigeria has shown that poor working conditions and a salary that is not commensurate with the hazards of the job has incentivised some rangers to relax on the job, allow poachers to enter, and to get involved in illegal hunting and fishing (Ogunjinmi et al. 2008). Inflexible work hours and a lack of leave benefits was also considered a barrier for rangers to effectively do their job and prevent or respond to wildlife crime (Kubania 2019). In addition, the excessive work hours and workrelated emotional distress can lead to burnout, which limits productivity. Several papers cited adequate training, living conditions, financial compensation, and judicial processes and support as factors that could positively influence the success of a ranger guard force and their capacity to prevent wildlife crime (Aung 2007; Kuiper et al. 2021; Spira et al. 2019; The Thin Green Line Foundation 2020b).

Unfortunately, budget cuts due to loss of tourism revenue due to COVID-19 have negatively affected rangers' ability to engage communities, perform wildlife law enforcement activities, and address HWC (Singh et al. 2021b). Reductions in ecotourism can also increase wildlife crime, as a reduction of tourist presence (and reduced ranger presence) has contributed to a widening gap in oversight (African Wildlife Foundation 2020; Anagnostou et al. 2021). Although many illegal hunters may be involved in wildlife crime as a result of multidimensional poverty social inequity, and historical injustices (Anagnostou et al. 2021), rangers in some areas often face members of sophisticated transnational wildlife trafficking networks. The persistent lack of ranger training and equipment is especially harmful when, while on patrols, rangers encounter organised crime groups who possess advanced equipment and technologies (Dudley et al. 2013; International Union for Conservation of Nature 2011a). In short, improving the welfare and employment conditions of rangers and decreasing their precarity generally will contribute to efforts to mitigate wildlife crime and HWC.

\subsection{What can be done to improve the employment conditions of rangers?}

Half of the papers $(n=49)$ offered solutions and ideas for interventions that could improve the employment conditions of rangers. Of these, 24 described interventions already implemented in some regions, while the remaining 25 provided suggestions and recommendations for additional possible solutions. All key interventions mentioned in the literature are included in Table 1.

Overall, the majority of the implemented or suggested interventions addressed the following two dimensions of precarious employment conditions concerning rangers: (i) lack of rights and protection and (ii) working conditions. Only a handful of studies targeted employment insecurity and income inadequacy. Several studies discussed solutions that could indirectly improve rangers' working conditions through addressing corruption, improving community relations, and gathering research evidence to document the extent and impact of precarious employment. Overall, the publications which focused on implemented interventions did not discuss the outcomes of the suggested interventions, which should be a key consideration for employers searching for suitable solutions (Gunn et al. 2021b). Additionally, the findings suggest that the majority of interventions, both implemented and suggested, lack a structured approach that would systematically address multiple dimensions of precarious employment, including employment insecurity, income insufficiency, lack of rights and protection in the employment relation, and problematic working conditions.

As evidenced by the dearth of structured, high-level interventions mentioned in the literature we reviewed, there is an alarming lack of recognition by governments around the world of the importance of rangers' work, their key contributions to society, the diversity of roles they fulfill, and the life-threatening hazards involved in the profession. Given that rangers face numerous risks in order to protect biodiversity, local communities, and park visitors, state governments should allocate more resources and invest more in improving ranger working conditions and professionalising the ranger sector to the same extent as some of the more well-recognised public employees (Ledford et al. 2021; Singh et al. 2021b). The recognition of rangers as essential workers, alongside police, border officials, firefighters, military, health, and emergency response workers (Afriyie et al. 2021; Ledford et al. 2021) would ensure the provision of essential equipment for rangers the same way that is done for other workers recognized as essential. This recognition would also mean that rangers do not have to rely on donations and support from community members and non-governmental organisations (NGOs) (Spira et al. 2019; The Thin Green Line Foundation 2020b). It is also imperative that relevant initiatives are adopted so that the workplace culture in parks and protected areas is made safe for all employees, regardless of ethnicity, age, gender, class, or any other demographic characteristics, particularly given the severity of stresses and dangers that are inherent in this profession. Thus, states should seek to improve and unify their anti-discrimination legal frameworks in accordance with ILO's Discrimination (Employment and Occupation) Convention (International Labour Organization 1958), while wildlife authorities and environmental agencies should seek to enforce such legislation in their own organisations. Efforts to protect wildlife and preserve biodiversity may be futile without a strong legal foundation to protect rangers.

Furthermore, although several countries have designated funding from stimulus packages to support protected areas and natural capital in the aftermath of the COVID-19, given 


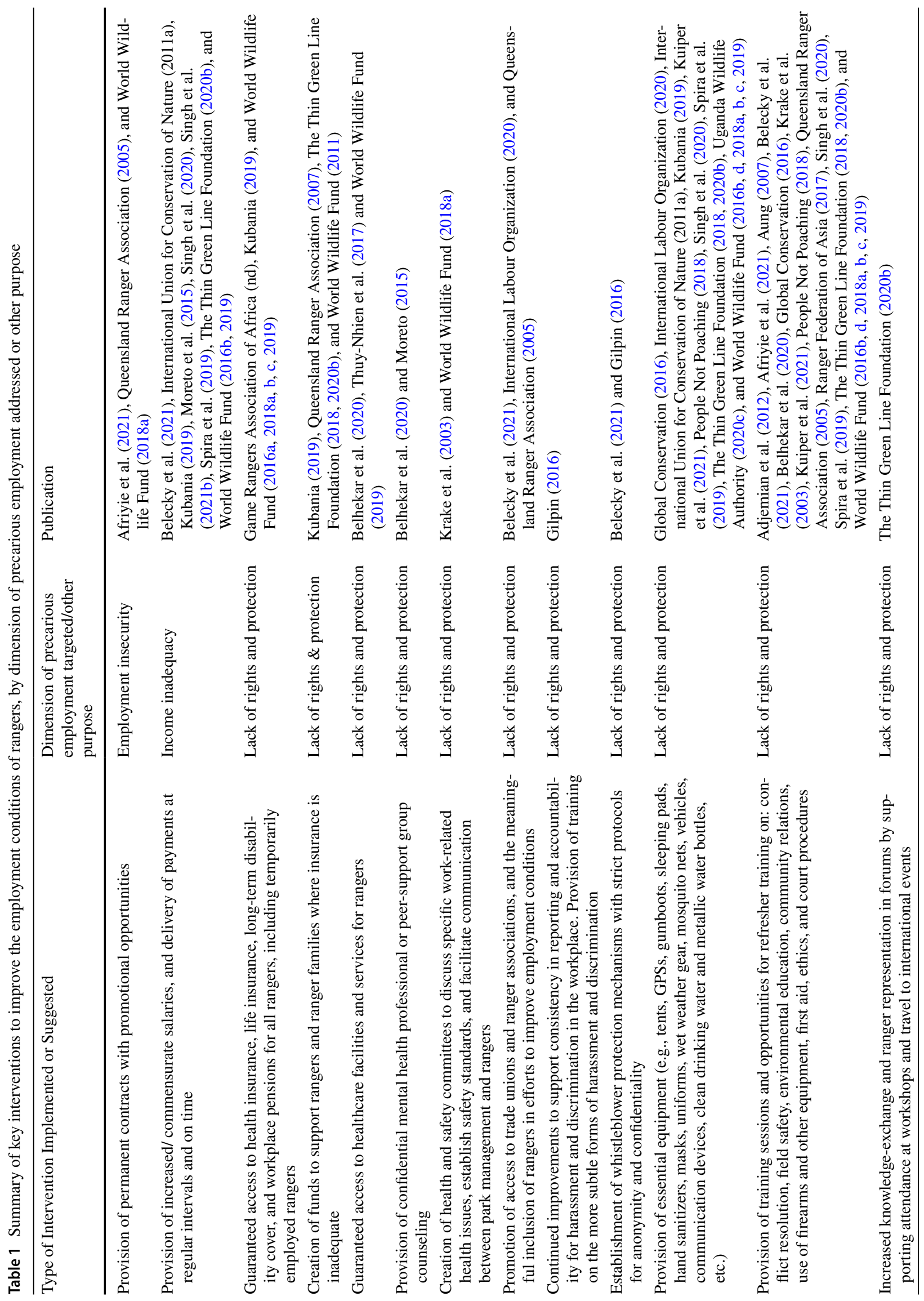




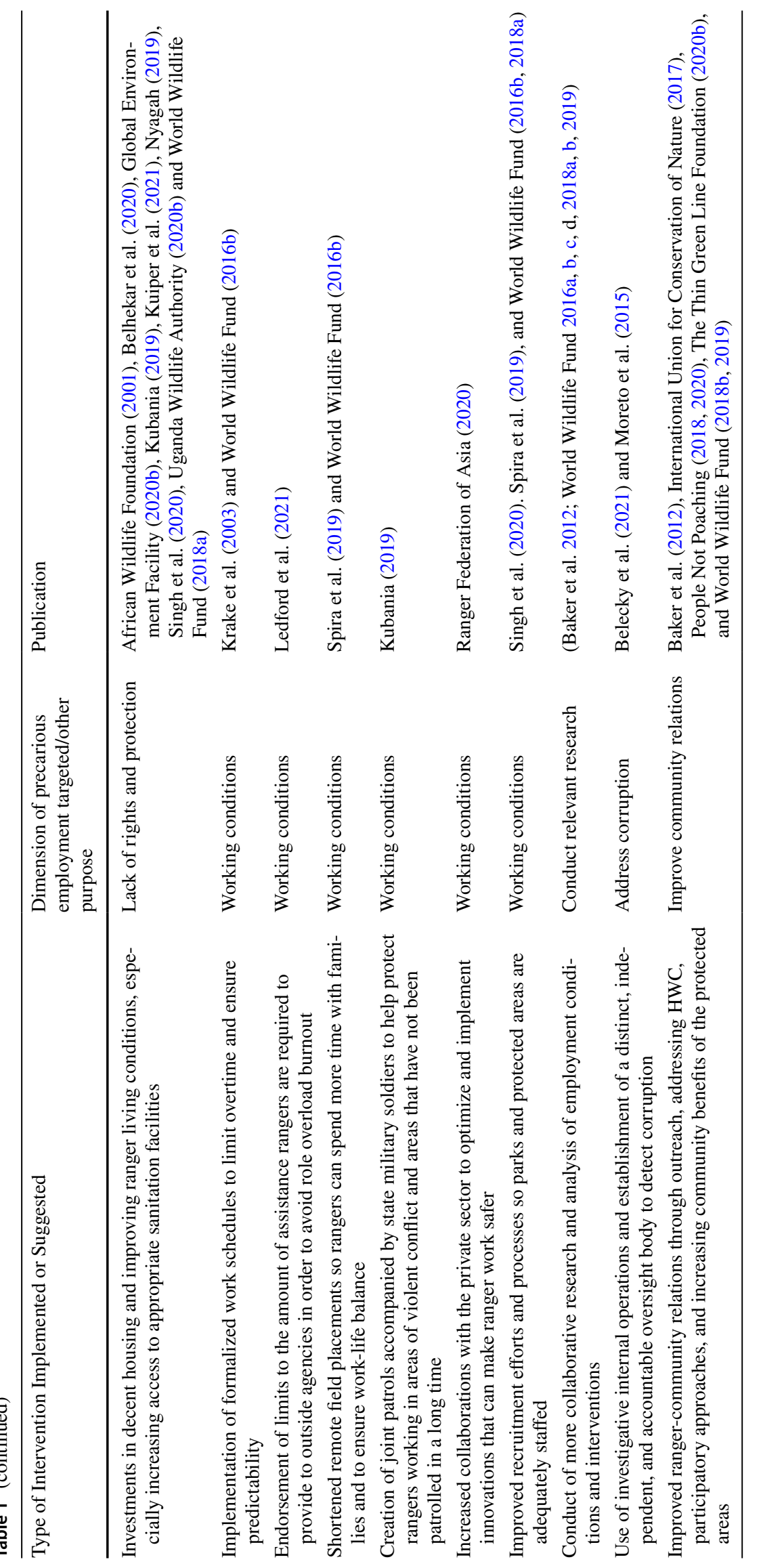


the current pandemic-related struggles experienced by rangers across the world, it is imperative that all rangers receive the support they need (International Union for Conservation of Nature 2021).

\subsection{Research gaps and implications}

Through our scoping review we were able to identify several research gaps that should be addressed to respond to the complexity of rangers' employment and working conditions, including occupational health issues. Firstly, the examination of relevant publications confirmed that the construct of precarious employment is very rarely used in relation to rangers, which could preclude an understanding of the ways in which precarious employment conditions affect workers. Not surprisingly, the examination of rangers' health and overall welfare in isolation from their employment and working conditions could also make it difficult to design solutions that target the source of problems, not only their symptoms. In addition, even when several aspects related to various dimensions of precarious employment are partially examined in ranger research studies, they are only rarely conceptualized together, which makes the accurate study of rangers' exposures to employment conditions and the related health outcomes quite challenging, if not impossible. In recent decades, the precarious employment framework has been applied with different population sub-groups including the youth, migrants, women, and people with disabilities (Canivet et al. 2016; Ornek et al. 2020; Vosko 2006) and various economic sectors, including agriculture, service sectors, and health care (Fité-Serra et al. 2019; Muntaner et al. 2006; Vosko 2006), often taking advantage of large population and labour market registries (Jonsson et al. 2021; Orellana et al. 2019; Vives et al. 2011). As a result, there is a large body of literature available should conservation, criminological, and environmental sustainability researchers focused on rangers become interested in applying this framework.

Secondly, although the use of the precarious employment construct would be a good start, an expanded theoretical framework that builds on it is needed to account for the intricacy of employment arrangements and occupational health issues identified by this review. Such an expanded framework could also borrow from or build on the frameworks developed by several major international organizations preoccupied with the health and well-being of workers. For instance, the European Foundation for the Improvement of Living and Working Conditions (Eurofound) uses the job quality framework, which is based on seven indices addressing different dimension of job quality including physical and social environment, intensity and quality of the work, skills and discretion, opportunities, and earnings (Eurofound 2021). Further, ILO uses the decent work approach, which incorporates workers' aspirations for productive work and fair incomes, workplace security, social protections, improved opportunities for personal development, freedoms of opinion and association, and equal treatment for all (ILO 2019). An acknowledged limitation of this framework is that is too broad and difficult to measure at a global level (ILO 2019). Other frameworks exist and, while there are many similarities and differences among such frameworks, they have the shared goal of improving job quality for workers and could be explored by researchers interested in examining various aspects of rangers' employment.

Thirdly, we identified a few specific research topics related to rangers' employment that would benefit from further exploration. For instance, although it has gained attention in recent years, research examining the effect of chronic under-staffing, under-funding, and lack of adequate equipment on rangers' work and their health and well-being should be expanded. This is especially important since most wildlife agencies lack the funding necessary to employ an optimal number of rangers (Aung 2007; Gardiner 2018; Global Environment Facility 2020b). For example, the Orkhon Valley National Park in Mongolia provides an extreme example, where just seven rangers are hired to cover 364,538 hectares, which means that each ranger is responsible for protecting roughly 52,000 hectares using horses as the primary mode of transportation (Global Environment Facility 2011). As previously emphasised, the limited number of staff presents an added danger when rangers encounter nonstate armed groups and poaching gangs, which can often outnumber the rangers (Spira et al. 2019). Closely related, the effectiveness of solutions that can solve this issue, such as 'poachers to protectors' initiatives, should be closely examined.

Furthermore, although limited research has been conducted to date to understand ranger workplace discrimination, findings from existing studies are alarming, signaling that this topic warrants more research attention. Few papers focus on the various marginalised groups that make up the ranger workforce globally. Fewer than $11 \%$ of the ranger workforce are women (McPherson 2021), and 99\% of our included studies focused on men. It is important that future studies seek to understand how the precarious employment conditions of rangers may differ based on existing inequalities, including racial and gender disparities, and how best to address these inequalities. In addition, despite including climate security in our methods as a topic for data extraction, we found only isolated mentions of the important role that rangers play in mitigating adverse climatic impacts on communities and wildlife. Similarly, we intended to extract data on the effects of ranger employment conditions on population health, however found limited data to draw from. The available evidence suggests that rangers who are not adequately housed, trained, and equipped may either contract infectious diseases which could, in turn, affect the broader population, or be unable to prevent illegal 
activities (e.g., bushmeat hunting) that drive zoonotic disease emergence. In addition, since four out of five rangers surveyed acknowledged the key role they play in controlling the spread of zoonotic diseases through wildlife conservation, education, and outreach with communities and park visitors (Singh et al. 2021b), more research is needed to understand the specific ways in which rangers can be better supported to mitigate both climate and public health threats.

Lastly, the majority of publications on the precarious employment conditions of rangers stems from grey literature reports, with limited peer-reviewed, empirical research. Future peer-reviewed studies could also seek to understand the employment conditions of rangers who are not employed by governments, such as Indigenous rangers, community scouts, and rangers in the NGOs or private sector (World Wildlife Fund 2016a). Specific regions, such as Central and South America, could also be the focus of future studies and meta-analyses that are inclusive of non-English publications to learn from the successes and ongoing challenges for improving ranger working and employment conditions in those regions.

\subsection{Limitations}

Despite our best efforts to conduct a thorough search and analysis of the literature focused on the precarious employment and working conditions of rangers, we acknowledge that some potentially relevant papers and sources may have been missed. This could be due to limiting our search, for practical reasons, to English language publications, which as a result, rendered publications from certain ranger organisations or geographic regions ineligible for inclusion in our study. In addition, not all of the websites belonging to relevant organisations had interfaces or archives that could be searched, limiting our ability to search for publications by key words. There may also have been grey literature that was inaccessible as older websites recreated or deleted content, refreshing, and removing older papers that may have been relevant to our review. These limitations to our study impacted the range of papers we were able to include but were unavoidable and, in our opinion, did not impact the reliability of the papers that were included or the outcomes of our study. Another limitation is the inadvertent loss of detail and richness of data arising from our attempt to summarize information across numerous studies, topics, and regions.

\section{Conclusion}

Our results clearly indicate that the majority of rangers currently practicing across multiple geographic regions experience various degrees of employment insecurity, income inadequacy, lack of workplace rights and protections, problematic working conditions, and several complex occupational health issues. As established through strong evidence, precarious employment conditions can be detrimental to workers' safety, mental health, physical health, and overall well-being. Given the wide range and complexity of employment arrangements and contextual factors that could affect rangers' health and well-being, the study of employment exposures and the outcomes they have on rangers requires a systematic and consistent approach that uses recognised theoretical frameworks and measures. For this reason, a theoretical approach that builds on established conceptualizations of the precarious employment construct and other related concepts should be developed. The adoption of such an approach would facilitate a better understanding of the complex effects of employment and working conditions as well as the adoption of relevant and sustainable solutions. In the shorter term, ranger recognition by governments as essential workers, alongside police, border officials, firefighters, military, health, and emergency response workers would facilitate their access to more secure funding and resources.

We hope that the approach we used in this scoping review to structure the precarious employment domains and related themes, along with the concrete findings, will spearhead further research on ranger-related employment and working conditions topics and trigger interest in applying similar lenses. Many of the issues rangers work to address, such as wildlife crimes, are complex, and can stem from historical injustices and enduring structural issues (Anagnostou et al. 2021). Therefore, while addressing the precarious employment of rangers will not singlehandedly solve these issues, it is an essential next step. Improving the employment and working conditions of rangers has implications that extend beyond rangers to affect broader society. Supporting rangers by improving their access to secure, full-time, and permanent contracts, adequate income, workplace rights, and workplace protections, along with addressing the whole range of other complex employment and occupational health issues they face will facilitate ongoing attempts to protect natural resources, support communities neighbouring protected areas, and ultimately, advance global biodiversity conservation efforts.

Supplementary Information The online version contains supplementary material available at https://doi.org/10.1007/s10669-022-09845-3.

Author contributions All authors made substantial contributions to the study. Conceptualization: MA, VG; methodology: MA, VG, ON; formal analysis and investigation: MA, VG, ON; writing—original draft preparation: MA; VG, ON; writing - review and editing: BD, CM. All authors read and approved the final manuscript.

Funding No funding was received for conducting this study. 
Availability of data and material Not applicable.

Code availability Not applicable.

\section{Declarations}

Conflict of interest The authors declare that they have no conflict of interest.

Ethical approval Not applicable.

Consent to participate Not applicable.

Consent for publication Not applicable.

\section{References}

Adjemian J, Weber IB, McQuiston J, Griffith KS, Mead PS, Nicholson W, Roche A, Schriefer M, Fischer M, Kosoy O (2012) Zoonotic infections among employees from Great Smoky Mountains and Rocky Mountain national parks, 2008-2009. Vector Borne Zoonotic Dis 12:922-931. https://doi.org/10.1089/vbz.2011.0917

African Parks (2015) Ranger killed by poachers in Garamba National Park, DRC. https://www.africanparks.org/newsroom/pressreleases/ranger-killed-by-poachers-garamba-national-park-drc. Accessed 12 July 2021

African Parks (2016) Three killed and two wounded by elephant poachers in Garamba National Park, DRC. https://www.africanpar ks.org/newsroom/press-releases/three-killed-and-two-wound ed-elephant-poachers-garamba-national-park-drc. Accessed 12 July 2021

African Parks (2020) Confirmation of the discovery of bodies of Matusadona rangers. https://www.africanparks.org/confirmation-disco very-bodies-matusadona-rangers. Accessed 12 July 2021

African Parks (nd) What does it mean to be a ranger? https://www. africanparks.org/what-does-it-mean-be-ranger. Accessed 12 July 2021

African Wildlife Foundation (2001) AWF presents new housing to Tanzania National Parks. https://www.awf.org/news/awf-prese nts-new-housing-tanzania-national-parks. Accessed 8 July 2021

African Wildlife Foundation (2003) The tragedies of poaching: Rangers killed in Tsavo. https://www.awf.org/news/tragedies-poach ing-rangers-killed-tsavo. Accessed 14 July 2021

African Wildlife Foundation (2006) Game officer killed by elephant poachers. https://www.awf.org/news/game-officer-killed-eleph ant-poachers. Accessed 14 July 2021

African Wildlife Foundation (2020) AWF mourns the loss of 12 rangers killed in Virunga National Park attack. https://www.awf.org/press room/awf-mourns-loss-12-rangers-killed-virunga-national-parkattack. Accessed 14 July 2021

African Wildlife Foundation (nd) Guarding the heart of the forest. https://www.awf.org/blog/guarding-heart-forest. Accessed 14 July 2021
Afriyie JO, Asare MO, Osei-Mensah J, Hejcmanová P (2021) Evaluation of long-term law enforcement monitoring in a West African protected area. Oryx. https://doi.org/10.1017/S00306053200002 28

Anagnostou M (2021) Synthesizing knowledge on crime convergence and the illegal wildlife trade. Environ Chall 5:100222. https://doi.org/10.1016/j.envc.2021.100222

Anagnostou M, Doberstein B (2021) Illegal wildlife trade and other organised crime: a scoping review. Ambio. https://doi.org/10. 1007/s13280-021-01675-y

Anagnostou M, Moreto WD, JGC, Doberstein B, (2021) Poverty, pandemics, and wildlife crime. Conserv Soc 19:294-306

Anagnostou M, Mwedde G, Roe D, Smith RJ, Travers H, Baker J (2020) Ranger perceptions of the role of local communities in providing actionable information on wildlife crime. Conserv Sci Pract 2:e202. https://doi.org/10.1111/csp2.202

Athanas A (2015) Protecting the protectors of Africa's world heritage. https://www.awf.org/blog/protecting-protectors-africa\% E2\%80\%99s-world-heritage. Accessed 14 July 2021

Atim Nchor A, Assam A, Nnadi PC (2021) Assessment of wildlife law enforcement practices in Cross River National Park, Nigeria. Int J Conserv Sci 12:647-658

Aung UM (2007) Policy and practice in Myanmar's protected area system. J Environ Manag 84:188-203. https://doi.org/10. 1016/j.jenvman.2006.05.016

Baker J, Milner-Gulland E, Leader-Williams N (2012) Park gazettement and integrated conservation and development as factors in community conflict at Bwindi Impenetrable Forest, Uganda. Conserv Biol 26:160-170. https://doi.org/10.1111/j.15231739.2011.01777.x

Belecky M, Moreto W, Parry-Jones R (2021) Corrupting conservation: Assessing how corruption impacts ranger work. https:// www.worldwildlife.org/pages/tnrc-topic-brief-corruptingconservation-assessing-how-corruption-impacts-ranger-work. Accessed 21 July 2021

Belhekar V, Paranjpye P, Bhatkhande A, Chavan R (2020) Guarding the guardians: understanding the psychological well-being of forest guards in Indian tiger reserves. Biodiversity 21:83-89. https://doi.org/10.1080/14888386.2020.1809521

Benach J, Muntaner C (2007) Precarious employment and health: developing a research agenda. J Epidemiol Community Health 61:276-277. https://doi.org/10.1136/jech.2005.045237

Benach J, Vives A, Tarafa G, Delclos C, Muntaner C (2016) What should we know about precarious employment and health in 2025 ? Framing the agenda for the next decade of research. Int J Epidemiol 45:232-238. https://doi.org/10.1093/ije/dyv342

Benach J, Vives A, Amable M, Vanroelen C, Tarafa G, Muntaner C (2014) Precarious employment: understanding an emerging social determinant of health. Annu Rev Public Health 35:229-253. https://doi.org/10.1146/annurev-publh ealth-032013-182500

Benach J, Castedo A, Solar O, Martínez JM, Vergara M, Amable M, Buxó M, Demiral Y, Muntaner C (2010) Methods for the study of employment relations and health inequalities in a global context. Int J Health Serv 40(2):209-213

Big Life Foundation (2018) Today, we stand with rangers. https:// biglife.org/program-updates/bush-journal/today-we-standwith-rangers. Accessed 15 July 2021

Bodin T, Çağlayan C, Garde AH, Gnesi M, Jonsson J, Kiran S, Kreshpaj B, Leinonen T, Mehlum IS, Nena E, Orellana C, Peckham T, Seixas N, Vanroelen C, Julia M (2019) Precarious employment in occupational health-an OMEGA-NET working group position paper. Scand J Work Environ Health 45:425-427. https://doi.org/10.5271/sjweh.3860

Canivet C, Bodin T, Emmelin M, Toivanen S, Moghaddassi M, Östergren P-O (2016) Precarious employment is a risk factor 
for poor mental health in young individuals in Sweden: a cohort study with multiple follow-ups. BMC Public Health 16:1-10. https://doi.org/10.1186/s12889-016-3358-5

Cárdenas J D (2020) Ex-FARC mafia drives park rangers out of Colombia's Amazon. https://insightcrime.org/news/brief/parkrangers-colombia-amazon/. Accessed 8 July 2021

Cochrane J (2020) COVID-19 reveals costly blind spots in efforts to combat wildlife crime. https://globalinitiative.net/analysis/ covid-19-blind-spots-wildlife-crime/. Accessed 24 July 2021

DeGroff K (2021) Lest we forget. https://www.npca.org/articles/ 2843-lest-we-forget. Accessed 14 July 2021

Dudley N, Stolton S, Elliott W (2013) Editorial: wildlife crime poses unique challenges to protected areas. https://doi.org/10.2305/ IUCN.CH.2013.PARKS-19-1.ND.en. Accessed 19 Aug 2021

Eliason SL (2011) Death in the line of duty: game warden mortality in the United States, 1886-2009. Am J Crim Justice 36:319326. https://doi.org/10.1007/s12103-010-9087-x

Environmental Investigation Agency (2014) Our respects to the fallen on World Ranger Day 2014. https://eia-international.org/ news/our-respects-to-the-fallen-on-world-ranger-day-2014/. Accessed 15 July 2021

Eurofound (2021) Working conditions and sustainable work: an analysis using the job quality framework. Publications Office of the European Union, Luxembourg

European Ranger Federation (2018) New attempt of homicide of a Spanish ranger. https://www.europeanrangers.org/new-attem pt-of-homicide-of-a-spanish-ranger/. Accessed 14 July 2021

Fité-Serra AM, Gea-Sánchez M, Alconada-Romero Á, Mateos JT, Blanco-Blanco J, Barallat-Gimeno E, Roca-Llobet J, Muntaner C (2019) Occupational precariousness of nursing staff in Catalonia's public and private nursing homes. Int J Environ Res Public Health 16:4921. https://doi.org/10.3390/ijerph16244921

Forsyth CJ, Forsyth YA (2009) Dire and sequestered meetings: the work of game wardens. Am J Crim Just 34:213-223. https:// doi.org/10.1007/s12103-009-9065-3

Game Rangers Association of Africa (nd) Ranger protect-project overview. https://www.gameranger.org/all-media/news/77ranger-protect-initiative.html. Accessed 23 July 2021

Gardiner C H (2018) Bolivia bust shows demand for wildlife in China. https://insightcrime.org/news/brief/bolivian-wildlifefilling-chinese-demand/. Accessed 8 July 2021

Gilpin L (2016) How the national park service is failing women. https://www.hcn.org/issues/48.21/how-the-park-service-is-faili ng-women. Accessed 14 July 2021

Global Conservation (2016) Park rangers on the frontline being killed at an astonishing rate from India to Thailand to Africa. https://globalconservation.org/news/park-rangers-frontlinebeing-killed-astonishing-rate-new-solutio/. Accessed 20 July 2021

Global Environment Facility (2011) One ranger, 52000 hectares. https://www.thegef.org/news/one-ranger-52000-hectares. Accessed 15 July 2021

Global Environment Facility (2020a) Risking lives to protect wildlife and wildlands: stories from rangers in the field. https://www.thegef.org/news/risking-lives-protect-wildlife-and-wildlands-stori es-rangers-field. Accessed 15 July 2021

Global Environment Facility (2020b) In vast Angolan National Park, rangers wear many hats. https://www.thegef.org/news/vast-angol an-national-park-rangers-wear-many-hats. Accessed 15 July 2021

Gunn V, Somani R, Muntaner C (2021) Health care workers and migrant health: Pre- and post-COVID-19 considerations for reviewing and expanding the research agenda. J Migr Health 4:1-8. https://doi.org/10.1016/j.jmh.2021.100048

Gunn V, Håkansta C, Vignola E, Matilla-Santander N, Kreshpaj B, Wegman DH, Hogstedt C, Ahonen EQ, Muntaner C, Baron S, Bodin T, The Precarious Work Research G (2021) Initiatives addressing precarious employment and its effects on workers' health and well-being: a protocol for a systematic review. Syst Rev 10:195. https://doi.org/10.1186/s13643-021-01728-z

Hadden WC, Muntaner C, Benach J, Gimeno D, Benavides FG (2007) A glossary for the social epidemiology of work organisation: Part 3, Terms from the sociology of labour markets. J Epidemiol Community Health 61:6-8. https://doi.org/10.1136/jech.2004. 032656

International Labour Organization (1947) Labour Inspection Convention, International Labour Organisation, C81. Adopted in Geneva, Switzerland on 11 July 1947. https://www.ilo.org/dyn/ normlex/en/f?p=NORMLEXPUB:12100:0::NO::P12100_ILO_ CODE:C081 Accessed 10 Aug 2021

International Labour Organization (1958) Discrimination (Employment and Occupation) Convention, International Labour Organisation, C111. Adopted in Geneva, Switzerland on 25 June 1958. https:// www.ilo.org/wcmsp5/groups/public/---ed_norm/---declaration/ documents/publication/wcms_decl_fs_85_en.pdf Accessed 10 Aug 2021

International Labour Organization (2016) Non-standard employment around the world: Understanding challenges, shaping prospects. https://www.ilo.org/global/publications/books/WCMS_534326/ lang--en/index.htm. Accessed 10 Aug 2021

International Labour Organization (2018) Decent work and the sustainable development goals: A Guidebook on SDG labour market indicators. https://www.ilo.org/wcmsp5/groups/public/---dgrep orts/---stat/documents/publication/wcms_647109.pdf. Accessed 10 Aug 2021

International Labour Organization (2020) Briefing note: Impact of COVID-19 on the forest sector. https://www.ilo.org/sector/Resou rces/publications/WCMS_749497/lang--en/index.htm. Accessed 20 July 20

International Union for Conservation of Nature (2011a) Nature- to die for? https://www.iucn.org/content/nature-die. Accessed 20 July 2021

International Union for Conservation of Nature (2011b) Worst attack on Virunga National Park rangers in years. https://www.iucn. org/content/worst-attack-virunga-national-park-rangers-years. Accessed 20 July 2021

International Union for Conservation of Nature (2014a) Rising murder toll of park rangers calls for tougher laws. https://www.iucn. org/content/rising-murder-toll-park-rangers-calls-tougher-laws. Accessed 20 July 2021

International Union for Conservation of Nature (2014b) True grit: life on the trail of the rosewood poachers. https://www.iucn.org/conte nt/true-grit-life-trail-rosewood-poachers. Accessed 20 July 2021

International Union for Conservation of Nature (2017) IUCN deplores ranger deaths in Garamba National Park. https://www.iucn.org/ news/secretariat/201704/iucn-deplores-ranger-deaths-garambanational-park. Accessed 20 July 2021

International Union for Conservation of Nature (2020) Erasto Fitz Maxwell Robertson: 'I have grown to know this country fairly well, but it is in getting lost that you get to know the country'. https://www.iucn.org/news/protected-areas/202007/erasto-fitzmaxwell-robertson-i-have-grown-know-country-fairly-well-itgetting-lost-you-get-know-country. Accessed 20 July 2021

International Union for Conservation of Nature (2021) COVID-19 fallout undermining nature conservation efforts. https://www. iucn.org/news/world-commission-protected-areas/202103/covid19-fallout-undermining-nature-conservation-efforts-iucn-publi cation. Accessed 20 July 2021

International Ranger Federation (2020) Who is a ranger? https://www. internationalrangers.org/. Accessed 13 Jan 2022

International Ranger Federation (2021) Ranger Code of Conduct Version 1.0. https://www.internationalrangers.org/toolkit/rangercode-of-conduct-2/. Accessed 13 Jan 2022 
ITV News (2016) Three park rangers dead after shootout with poachers. https://www.itv.com/news/2016-04-25/three-park-rangersdead-after-shootout-with-poachers. Accessed 12 July 2021

Jonsson J, Muntaner C, Bodin T, Alderling M, Balogh R, Burström B, Davis L, Gunn V, Hemmingsson T, Julià M, Kjellberg K, Kreshpaj B, Orellana C, Padrosa E, Wegman DH, MatillaSantander N (2021) Low-quality employment trajectories and risk of common mental disorders, substance use disorders and suicide attempt: a longitudinal study of the Swedish workforce. Scand J Work Environ Health 47:208-216. https://doi.org/10. 5271/sjweh.3978

Julià M, Vanroelen C, Bosmans K, Van Aerden K, Benach J (2017) Precarious employment and quality of employment in relation to health and well-being in Europe. Int J Health Serv 47:389-409. https://doi.org/10.1177/0020731417707491

Ko M (2001) Why no sidearms? Wardens report growing lawlessness in national parks, but Ottawa refuses to issue them pistols. https:// regroup-production.s3.amazonaws.com/documents/ReviewRefe rence/350533880/Why_no_sidearms.pdf?AWSAccessKeyId= AKIAJBZQODCMKJA4H7DA\&Expires $=1629492035 \&$ Signa ture $=2 \mathrm{O} \% 2 \mathrm{FJflFCUzPq} \% 2 \mathrm{FxNdzcMZnKAI7W8} \% 3 \mathrm{D}$. Accessed 15 July 2021

Koranyi I, Jonsson J, Rönnblad T, Stockfelt L, Bodin T (2018) Precarious employment and occupational accidents and injuries-a systematic review. Scand J Work Environ Health 44:341-350. https://doi.org/10.5271/sjweh.3720

Krake A, McCullough J, King B (2003) Health hazards to park rangers from excessive heat at Grand Canyon National Park. Appl Occup Environ Hyg 18:295-317. https://doi.org/10.1080/10473 220301364

Kreshpaj B, Orellana C, Burström B, Davis L, Hemmingsson T, Johansson G, Kjellberg K, Jonsson J, Wegman DH, Bodin T (2020) What is precarious employment? A systematic review of definitions and operationalizations from quantitative and qualitative studies. Scand J Work Environ Health 46:235-247. https:// doi.org/10.5271/sjweh.3875

Kubania J (2019) Meet the men and women fighting to protect biodiversity in DRC's Bili-Uele landscape. https://www.awf.org/ blog/meet-men-and-women-fighting-protect-biodiversity-drcsbili-uele-landscape. Accessed 14 July 2021

Kuiper T, Massé F, Ngwenya NA, Kavhu B, Mandisodza-Chikerema RL, Milner-Gulland EJ (2021) Ranger perceptions of, and engagement with, monitoring of elephant poaching. People and Nature 3:148-161. https://doi.org/10.1002/pan3.10154

Kuvawoga P (2020) Custodians of nature: A peek into a rangers camp under the COVID-19 pandemic in Hwange National Park. https:// www.ifaw.org/ca-en/journal/rangers-camp-covid-19-hwangenational-park. Accessed 16 July 2021

Ledford LS, Osborne DL, Edwards BD, Stickle B (2021) Not just a walk in the woods? Exploring the impact of individual characteristics and changing job roles on stress among conservation officers. Police Pract Res 22:274-289. https://doi.org/10.1080/ 15614263.2020 .1821682

Lewchuk W (2017) Precarious jobs: where are they, and how do they affect well-being? Econ Labour Relat Rev 28:402-419

Mararv E (2015) Account of events October 5th-8th resulting in four rangers killed in action, Garamba National Park, DRC. https:// www.africanparks.org/newsroom/press-releases/account-eventsoctober-5th-8th-resulting-four-rangers-killed-action-garambanational-park-drc. Accessed 12 July 2021

Margaryan G (2013) Two Kenya wildlife service rangers killed by suspected poachers. https://www.awf.org/blog/two-kenya-wildl ife-service-rangers-killed-suspected-poachers. Accessed 14 July 2021

Matilla-Santander N, Gonzalez-Marron A, Martin-Sanchez JC, Lidon-Moyano C, Cartanya-Hueso A, Martinez-Sanchez JM
(2019) Precarious employment and health-related outcomes in the European Union: a cross-sectional study. Crit Public Health 30:429-440. https://doi.org/10.1080/09581596.2019.1587385

Matilla-Santander N, Ahonen E, Albin M, Baron S, Bolibar M, Bosmans K, Burstrom B, Cuervo I, Davis L, Gunn V, Hakansta C, Hemmingsson T, Hogstedt C, Jonsson J, Julia M, Kjellberg K, Kreshpaj B, Lewchuk W, Muntaner C, O’Campo P, Orellana C, Ostergren P-O, Padrosa E, Ruiz ME, Vanroelen C, Vignola E, Vives A, Wegman DH, PWR Study Consortium (2021) COVID19 and precarious employment: consequences of the evolving crisis. Int J Health Serv 51:1-3. https://doi.org/10.1177/00207 31420986694

McConnell T (2018) The bloody toll of Congo's elephant wars. https:// www.gq.com/story/inside-the-ivory-wars. Accessed 8 July 2021

McPherson A (2021) Wildlife rangers: why they are nature's first responders, and why they need more support. https://www.disco verwildlife.com/people/wildlife-rangers-why-they-are-naturesfirst-responders-and-why-they-need-more-support/. Accessed 19 Aug 2021

Moher D, Liberati A, Tetzlaff J, Altman DG (2009) Preferred reporting items for systematic reviews and meta-analyses: the PRISMA statement. PLoS Med 6:e1000097-e1000097. https://doi.org/10. 1371/journal.pmed.1000097

Moreto WD (2015) Occupational stress among law enforcement rangers: insights from Uganda. Oryx 50:646-654. https://doi.org/10. 1017/S0030605315000356

Moreto WD, Brunson RK, Braga AA (2015) 'Such misconducts don't make a good ranger': examining law enforcement ranger wrongdoing in Uganda. Br J Criminol 55:359-380. https://doi.org/10. 1093/bjc/azu079

Moreto WD, Gau JM, Paoline EA, Singh R, Belecky M, Long B (2019) Occupational motivation and intergenerational linkages of rangers in Asia. Oryx 53:450-459. https://doi.org/10.1017/S0030 605317001041

Muntaner C, O'Campo PJ (1993) A critical appraisal of the demand/ control model of the psychosocial work environment: epistemological, social, behavioral and class considerations. Soc Sci Med 36:1509-1517. https://doi.org/10.1016/0277-9536(93)90393-I

Muntaner C, Li Y, Xue X, Thompson T, O'Campo P, Chung H, Eaton WW (2006) County level socioeconomic position, work organization and depression disorder: a repeated measures cross-classified multilevel analysis of low-income nursing home workers. Health Place 12:688-700. https://doi.org/10.1016/j.healthplace. 2005.09.004

Muntaner C, Borrell C, Vanroelen C, Chung H, Benach J, Kim IH, $\mathrm{Ng}$ E (2010) Employment relations, social class and health: a review and analysis of conceptual and measurement alternatives. Soc Sci Med 71:2130-2140. https://doi.org/10.1016/j.socscimed. 2010.09.038

Muntaner C, Ng E, Gunn V, Shahidi FV, Vives A, Finn Mahabir D, Chung H (2020) Precarious employment conditions, exploitation, and health in two global regions: Latin America and the Caribbean and East Asia. In: Theorell T (ed) Handbook of socioeconomic determinants of occupational health. handbook series in occupational health sciences. Springer, Cham. https://doi.org/10. 1007/978-3-030-05031-3

Nagy EE, Rácz A, Urbán E, Terhes G, Berki T, Horváth E, Georgescu AM, Zaharia-Kézdi IE (2016) Diagnostic pitfalls in a young Romanian ranger with an acute psychotic episode. Neuropsychiatr Dis Treat 12:961. https://doi.org/10.2147/NDT.S103300

Newman P (2015) Demand for rosewoods drives Cambodia forest murders. https://eia-international.org/blog/demand-for-rosew oods-drives-cambodia-forest-murders/. Accessed 15 July 2021

Nyagah J (2019) Keeping wildlife protected through community ranger housing. https://www.ifaw.org/ca-en/journal/ranger-housing. Accessed 16 July 2021 
Ogunjinmi A, Umunna M, Ogunjinmi K (2008) Factors affecting job satisfaction of rangers in Yankari Game Reserve, Bauchi, Nigeria. J Agric Soc Res 8:2. https://doi.org/10.4314/jasr.v8i2.43332

Orellana C, Kreshpaj B, Johansson G, Burström B, Kjellberg K, Hemmingsson T, Axen M, Davis L, Wegman D, Bodin T (2019) Precarious employment, business performance and occupational injuries: a study protocol of a register-based Swedish project. BMJ Open 9:e026091. https://doi.org/10.1136/bmjop en-2018-026091

Ornek OK, Weinmann T, Waibel J, Radon K (2020) Precarious employment and migrant workers' mental health: a protocol for a systematic review of observational studies. Syst Rev 9:50. https:// doi.org/10.1186/s13643-020-01313-w

Pashkevich A, Stjernström O (2014) Making Russian Arctic accessible for tourists: analysis of the institutional barriers. Polar Geogr 37:137-156. https://doi.org/10.1080/1088937X.2014.919040

Pennaz ABK (2017) Is that gun for the bears? The national park service ranger as a historically contradictory figure. Conserv Soc $15: 243-254$

People Not Poaching (2018) Tackling illegal logging in Ulu Masen, Aceh https://www.peoplenotpoaching.org/tackling-illegal-loggi ng-ulu-masen-aceh. Accessed 20 July 2021

People Not Poaching (2020) Supporting communities and law enforcement in the Greater Kafue ecosystem https://www.peoplenotp oaching.org/supporting-communities-and-law-enforcement-great er-kafue-ecosystem. Accessed 20 July 2021

Peters MDJ, Marnie C, Tricco AC, Pollock D, Munn Z, Alexander L, McInerney P, Godfrey CM, Khalil H (2020) Updated methodological guidance for the conduct of scoping reviews. JBI Evid Synth 18:2119-2126. https://doi.org/10.11124/JBIES-20-00167

Poppe J (2012) Conservation's ambiguities: rangers on the periphery of the W Park, Burkina Faso. Conserv Soc 10:330-343

Queensland Ranger Association (2004) Welcome to the Ranger Rambler. http://queenslandranger.org/wp-content/uploads/2015/04/ Ranger-Rambler-Issue-1_Feb-2004.pdf. Accessed 14 July 2021

Queensland Ranger Association (2005) Message from the Australian Workers Union (AWU) - Unity is strength. http://queensland ranger.org/wp-content/uploads/2015/04/Ranger-Rambler-Issue1_Feb-2004.pdf. Accessed 14 July 2021

Queensland Ranger Association (2007) New QRA Family Support Fund. http://queenslandranger.org/wp-content/uploads/2015/ 04/Ranger-Rambler-Issue-8_Summer-2007.pdf. Accessed 14 July 2021

Ranger Federation of Asia (2016) Lack of support endangers wildlife rangers. https://rangerfederationasia.org/lack-of-support-endan gers-wildlife-rangers/. Accessed 21 July 2021

Ranger Federation of Asia (2017) New field ranger training guidelines, could save the lives of those on the front line of the poaching battle. https://rangerfederationasia.org/new-field-ranger-train ing-guidelines-could-save-the-lives-of-those-on-the-front-lineof-the-poaching-battle/. Accessed 21 July 2021

Ranger Federation of Asia (2020) Rangers health and safety - World day for safety and health at work. https://rangerfederationasia. org/rangers-health-and-safety-world-day-for-safety-and-healthat-work/. Accessed 20 July 2021

Robbins S (2019) The increasing dangers facing Latin America's park rangers. https://insightcrime.org/news/analysis/park-ranger-killi ngs-latin-america/. Accessed 8 July 2021

Rönnblad T, Grönholm E, Jonsson J, Koranyi I, Orellana C, Kreshpaj B, Chen L, Stockfelt L, Bodin T (2019) Precarious employment and mental health: a systematic review and meta-analysis of longitudinal studies. Scand J Work Environ Health 45:429-443. https://doi.org/10.5271/sjweh.3797

Safonova T (2007) The professional ethos of rangers in Russian nature reserves. Acta Borealia 24:44-58. https://doi.org/10.1080/08003 830701411613
Shanahan M (2013) Time to join the dots on environmental murders. https://www.iied.org/time-join-dots-environmental-murders. Accessed 20 July 2021

Seager J, Bowser G, Dutta A (2021) Where are the women? Towards gender equality in the ranger workforce. Parks Steward Forum 37:206-218. https://doi.org/10.5070/P537151751

Singh R, Gan M, Barlow C, Long B, Mcvey D, De Kock R, Gajardo OB, Avino FS, Belecky M (2020) What do rangers feel? Perceptions from Asia, Africa and Latin America. https://parks journal.com/wp-content/uploads/2020/06/10.2305-IUCN. CH_.2020PARKS-26-1en-low-resolution_new.pdf\#page $=63$. Accessed 14 July 2021

Singh R, Galliers C, Appleton M, Hoffmann M, Long B, Cary-Elwes J, Fritze C, McCallum J, Parry Jones R (2021a) The vital role of rangers in conservation. Parks Steward Forum 37:128-163. https://doi.org/10.5070/P537151745

Singh R, Galliers C, Moreto W, Slade J, Long B, Aisha H, Wright A, Cartwright F, Deokar A, Wyatt A (2021b) Impact of the Covid19 pandemic on rangers and the role of rangers as a planetary health service. https://www.internationalrangers.org/wp-conte nt/uploads/Singh_et_al10.2305-IUCN.CH_.2021.PARKS-27SIRS.en_-12.pdf. Accessed 14 July 2021

Spira C, Kirkby AE, Plumptre AJ (2019) Understanding ranger motivation and job satisfaction to improve wildlife protection in Kahuzi-Biega National Park, eastern Democratic Republic of the Congo. Oryx 53:460-468. https://doi.org/10.1017/S0030 605318000856

Stellar J (2017) Human rights in a hostile environment. https://globa linitiative.net/analysis/human-rights-in-a-hostile-environment/. Accessed 24 July 2021

Stevenson S, Gowardman J, Tozer S, Woods M (2015) Life-threatening Q fever infection following exposure to kangaroos and wallabies. Case Rep 2015:bcr2015210808. https://doi.org/10.1136/ bcr-2015-210808

Thakholi L (2021) Conservation labour geographies: Subsuming regional labour into private conservation spaces in South Africa. Geoforum 123:1-11. https://doi.org/10.1016/j.geoforum.2021. 04.019

The Thin Green Line Foundation (2018) Annual report 2016-2017. https://thingreenline.org.au/the-thin-green-line-foundation-20162017-annual-report/. Accessed 12 July 2021

The Thin Green Line Foundation (2020a) Nature's protectors - Deadly toll. https://thingreenline.org.au/natures-protectors-deadly-toll/. Accessed 24 July 2021

The Thin Green Line Foundation (2020b) Annual report 2019-2020. https://thingreenline.org.au/annual-report-2019-2020/. Accessed July 122021

Thuy-Nhien N, von Seidlein L, Le Phuc-Nhi T, Phu NT, Tuyen NTK, Tran NH, Van Dung N, Van Quan B, Day NP, Dondorp AM (2017) The prevalence, incidence and prevention of Plasmodium falciparum infections in forest rangers in Bu Gia Map National Park, Binh Phuoc province, Vietnam: a pilot study. Malar J 16:110. https://doi.org/10.1186/s12936-017-2091-6

Uganda Wildlife Authority (2020a) Ranger on duty killed by elephants. https://www.ugandawildlife.org/component/k2/ranger-on-dutykilled-by-elephants. Accessed 24 July 2021

Uganda Wildlife Authority (2020b) Ruhija sector - Bwindi Mgahinga Conservation Area gets 12 unit accommodation block. https:// www.ugandawildlife.org/component/k2/ruhija-sector-\%E2\% 80\%93-bwindi-mgahinga-conservation-area-gets-12-unit-accom modation-block. Accessed 24 July 2021

Uganda Wildlife Authority (2020c) African Wildlife Foundation donates ranger operations gear for field patrols. https://www. ugandawildlife.org/component/k2/african-wildlife-foundation. Accessed 24 July 2021 
Uganda Wildlife Authority (2020d) Ranger on duty killed by armed poachers. https://www.ugandawildlife.org/component/k2/pressrelease-ranger-on-duty-killed-by-armed-poachers. Accessed 24 July 2021

United Nations (2018) Dangerous job for South African wildlife rangers despite new technology. https://www.unep.org/news-and-stori es/story/dangerous-job-south-african-wildlife-rangers-despitenew-technology. Accessed 21 July 2021

United Nations General Assembly (1948) Universal Declaration of Human Rights. United Nations General Assembly, signed in Paris on 10 December 1948 art.25. https://www.un.org/en/udhrb ook/pdf/udhr_booklet_en_web.pdf. Accessed 20 July 2021

Vives A, Amable M, Ferrer M, Moncada S, Llorens C, Muntaner C, Benavides FG, Benach J (2010) The Employment Precariousness Scale (EPRES): psychometric properties of a new tool for epidemiological studies among waged and salaried workers. BMJ Occup Environ Med 67:548-555. https://doi.org/10.1136/oem. 2009.048967

Vives A, Vanroelen C, Amable M, Montserrat F, Moncada S, Llorens C, Muntaner C, Benavides FG, Benach J (2011) Employment precariousness in Spain: prevalence, social distribution, and population-attributable risk percent of poor mental health. Int J Health Serv 41:625-646. https://doi.org/10.2190/HS.41.4.b

Vosko LF (2006) Precarious employment: understanding labour market insecurity in Canada. McGill-Queen's University Press, Montreal

Wildlife Conservation Society (2016) Park ranger murdered in last gorilla stronghold. https://newsroom.wcs.org/News-Releases/ articleType/ArticleView/articleId/9354/Park-Ranger-Murderedin-Last-Gorilla-Stronghold.aspx. Accessed 21 July 2021

Wildlife Conservation Society (2018) Statement from WCS on the killing of three conservation heroes in Cambodia. https://newsr oom.wcs.org/News-Releases/articleType/ArticleView/articleId/ 10973/Statement-from-WCS-on-the-Killing-of-Three-Conservati on-Heroes-in-Cambodia.aspx. Accessed 21 July 2021

World Wildlife Fund (2011) WWF mourns death of Virunga National Park ranger https://www.worldwildlife.org/stories/wwf-mournsdeath-of-virunga-national-park-ranger. Accessed 21 July 2021
World Wildlife Fund (2016a) Ranger Insurance Report. https://d2ouv y59p0dg6k.cloudfront.net/downloads/ranger_insurance_report_ final_.pdf. Accessed 3 Aug 2021

World Wildlife Fund (2016b) Ranger Perception: Asia. https://www. worldwildlife.org/publications/ranger-perception-asia. Accessed 3 Aug 2021

World Wildlife Fund (2016c) Is a personal commitment to conservation enough to keep rangers on the job? https://www.worldwildl ife.org/magazine/issues/fall-2016/articles/is-a-personal-commi tment-to-conservation-enough-to-keep-rangers-on-the-job. Accessed 12 July 2021

World Wildlife Fund (2016d) Ranger Perceptions: Africa https:// www.worldwildlife.org/publications/ranger-perceptions-africa. Accessed 21 July 2021

World Wildlife Fund (2016e) Tragic year for world's rangers, many of whom lack even basic insurance. https://www.worldwildlife.org/ press-releases/tragic-year-for-world-s-rangers-many-of-whomlack-even-basic-insurance. Accessed Aug 32021

World Wildlife Fund (2018a) Ranger perceptions: Central America. https://www.globalwildlife.org/wp-content/uploads/2019/09/ ranger-survey-english.pdf. Accessed 21 July 2021

World Wildlife Fund (2018b) Life on the frontline 2018: A global survey of the working conditions of rangers. https://www.world wildlife.org/publications/life-on-the-frontline-2018. Accessed 3 Aug 2021

World Wildlife Fund (2018c) New survey finds one in seven wildlife rangers have been seriously injured in the line of duty over the past year. https://www.worldwildlife.org/press-releases/newsurvey-finds-one-in-seven-wildlife-rangers-have-been-serio usly-injured-in-the-line-of-duty-over-the-past-year. Accessed 3 August 2021

World Wildlife Fund (2019) Life on the frontline 2019: A global survey of the working conditions of rangers. https://www.worldwildlife. org/publications/life-on-the-frontline-2019-a-global-survey-ofthe-working-conditions-of-rangers. Accessed 3 Aug 2021 